\title{
Sodium as nutrient and toxicant
}

\author{
Herbert J. Kronzucker • Devrim Coskun • \\ Lasse M. Schulze • Jessie R. Wong • Dev T. Britto
}

Received: 27 March 2013 /Accepted: 31 May 2013 /Published online: 22 June 2013

(C) Springer Science+Business Media Dordrecht 2013

\begin{abstract}
Background Sodium $\left(\mathrm{Na}^{+}\right)$is one of the most intensely researched ions in plant biology and has attained a reputation for its toxic qualities. Following the principle of Theophrastus Bombastus von Hohenheim (Paracelsus), $\mathrm{Na}^{+}$is, however, beneficial to many species at lower levels of supply, and in some, such as certain $\mathrm{C} 4$ species, indeed essential.

Scope Here, we review the ion's divergent roles as a nutrient and toxicant, focusing on growth responses, membrane transport, stomatal function, and paradigms of ion accumulation and sequestration. We examine connections between the nutritional and toxic roles throughout, and place special emphasis on the relationship of $\mathrm{Na}^{+}$to plant potassium $\left(\mathrm{K}^{+}\right)$relations and homeostasis. Conclusions Our review investigates intriguing connections and disconnections between $\mathrm{Na}^{+}$nutrition and toxicity, and concludes that several leading paradigms in the field, such as on the roles of $\mathrm{Na}^{+}$influx and tissue
\end{abstract}

Responsible Editor: Philippe Hinsinger.

H. J. Kronzucker $(\bowtie) \cdot$ D. Coskun • L. M. Schulze •

J. R. Wong · D. T. Britto

Department of Biological Sciences, University of Toronto,

1265 Military Trail, Toronto, ON, Canada M1C 1A4

e-mail: herbertk@utsc.utoronto.ca

D. Coskun

e-mail: devrim.coskun@mail.utoronto.ca

L. M. Schulze

e-mail: lasse.schulze@utoronto.ca

J. R. Wong

e-mail: jessierachel.wong@mail.utoronto.ca

D. T. Britto

e-mail: brito@utsc.utoronto.ca accumulation or the cytosolic $\mathrm{K}^{+} / \mathrm{Na}^{+}$ratio in the development of toxicity, are currently insufficiently substantiated and require a new, critical approach.

Keywords Salinity · Sodium · Plant nutrition · Sodium toxicity $\cdot$ Ion transport $\cdot$ Potassium

\section{Introduction}

Sodium is the sixth most abundant element in earth's crust, where it comprises some $2.8 \%$ (Lutgens and Tarbuck 2003), and, after chloride, is the second most abundant solute in the oceans. In the latter, it typically prevails at concentrations near $470 \mathrm{mM}$ (Harris 1996; Epstein and Bloom 2005), and these can be higher still in areas of high evaporation and limited rainfall, such as regions near $30^{\circ}$ latitude. It is instructive to ponder the evolution of early life in this salt-dominated environment, and it, thus, comes as little surprise that marine organisms, from protists to animals, are highly salt-tolerant, and indeed require $\mathrm{Na}^{+}$for survival. Even in terrestrial animals, $\mathrm{Na}^{+}$has retained its role as an essential nutrient. In mammals, blood serum $\mathrm{Na}^{+}$concentrations are held high, by virtue of strict homeostatic mechanisms (see e.g. Grinstein and Rothstein 1986), near 135-145 mM, and even higher levels are routinely achieved in the renal system and in urine (Segen and Stauffer 1998). By contrast, the majority of land plants, when exposed to concentrations similar to those found in the mammalian blood stream, let alone that of the oceans, suffers moderate to severe toxicity symptoms. Such concentrations are, however, 
frequently found, and exceeded, in soils, and this occurs rarely as a uniform distribution but is associated with much spatial heterogeneity (Bazihizina et al. 2012). Only a few groups of terrestrial plants, the halophytes, have (re-)-acquired the ability to tolerate, and indeed thrive on, high- $\mathrm{Na}^{+}$media, while others, however, appear to have the ability to utilize the $\mathrm{Na}^{+}$ion for several key cellular processes and can benefit from sodium's presence, as long as supply concentrations remain below osmotically challenging ones. Here, we will focus on the literature covering these beneficial effects in higher plants, with a special emphasis on the few mechanistic explanations that have emerged, and, in addition, on salient open questions in the otherwise more thoroughly researched area of sodium toxicity, in particular as they relate to, or emanate from, deliberations of the former. Special focus will also be brought to interactions between sodium and potassium, wherein much insight into mechanisms of growth and performance enhancement as well as impairment can be found.

\section{Sodium as a nutrient}

From beet to chocolate: the classic literature $-\mathrm{Na}^{+}$ benefits are common

It has long been known that $\mathrm{Na}^{+}$can be of benefit to the growth of algae and cyanobacteria (Allen and Arnon 1955; Simonis and Urbach 1963; Brownell and Nicholas 1968), but, for higher plants, the reputation of the ion as a toxic one has held sway (Maathuis 2007; Munns and Tester 2008; Kronzucker and Britto 2011; Cheeseman 2013), and the vast majority of higher-plant literature on the ion has focused on this aspect, even though studies in a wide variety of species, including such important cultivated ones as tomato, potato, carrot, cacao, and cereals, have demonstrated the potential benefit of the ion for higher-plant growth as well (Wheeler and Adams 1905; Lehr 1941; Lehr and Wybenga 1955; Woolley 1957; Williams 1960; Brownell 1965; Brownell and Jackman 1966; Montasir et al. 1966; El-Sheikh et al. 1967; Hylton et al. 1967; Draycott and Durrant 1976; Galeev 1990; Takahashi and Maejima 1998; Gattward et al. 2012). It is important to emphasize that every substance has a threshold below which it is not toxic, in accordance with the "sola dosis facit venemum" (only the dose makes the poison) principle, famously attributed to Theophrastus Bombastus von Hohenheim (Paracelsus), but, for $\mathrm{Na}^{+}$, beneficial effects are seen well into the range of concentrations that would be considered high for ordinary nutrient ions, such as $\mathrm{NO}_{3}^{-}, \mathrm{NH}_{4}^{+}$, or $\mathrm{K}^{+}$, and, in the cases of halophytes, go far beyond that (Flowers and Colmer 2008). Many of the studies on beneficial effects have focused on the partial to near-complete replacement of potassium by sodium, typically in the concentration range of several millimolar, reporting either no negative, or indeed palpably positive, effects on plant growth and yield. In many of the cases, growth was particularly stimulated when $\mathrm{K}^{+}$supply was low, and plants suffered at least partial $\mathrm{K}^{+}$deprivation (Mullison and Mullison 1942; Wallace et al. 1948; Lehr 1950; Cope et al. 1953; Lancaster et al. 1953; Lehr 1953; Gammon 1953; Truog et al. 1953; Ulrich and Ohki 1956; Flowers and Läuchli 1983; Subbarao et al. 2001; Subbarao et al. 2003).

Tables 1, 2, and 3 summarize a substantial body of studies that have reported such beneficial effects, listing the species examined, the parameters reported, and the $\mathrm{Na}^{+}$concentrations at which effects were seen. Aside from growth (improved root and shoot biomass) and yield, results in early studies were often reported as readily visible changes, such as improvement in colour (i.e. greener leaves) and its maintenance in later growth stages, and, related to this, less pronounced manifestations of nutrient deficiency (chlorosis or necrosis), or greater "gloss" on leaves, suggesting an increase in cuticular wax formation (Harmer and Benne 1945; Brownell and Crossland 1972). Other reports have commented on the taste and texture of crops grown with additions of sodium (Harmer and Benne 1945; Truog 1953; Zhang and Blumwald 2001).

Among the species examined, the Chenopodiaceae, including the important crops spinach, beet, and sugar beet, have received particularly detailed attention, both in terms of physiological and field investigation (Larson and Pierre 1953; Lehr and Wybenga 1955; Tinker 1965; El-Sheikh et al. 1967; Draycott et al. 1970; Judel and Kuhn 1975; Draycott and Durrant 1976; Jeschke 1977; Milford et al. 1977; Durrant et al. 1978; Draycott and Bugg 1982; Flowers and Läuchli 1983; Nunes et al. 1984; Pessarakli and Tucker 1985; Peck et al. 1987; Magat and Goh 1990; Haneklaus et al. 1998; Subbarao et al. 1999a, b). Beneficial effects in this family are pronounced, and 
Table 1 Survey of published studies that report $\mathrm{Na}^{+}$as a beneficial nutrient (micronutrient, $\leq 1 \mathrm{mM}$ ) for some plant species

\begin{tabular}{|c|c|c|c|}
\hline Species & {$\left[\mathrm{Na}^{+}\right]_{\text {external }}$} & Measure(s) improved by $\mathrm{Na}^{+}$ & Reference \\
\hline $\begin{array}{l}\text { Barley (Hordeum vulgare), Atriplex nummularia, } \\
\text { A. paludosa, A. quinii, A. semibaccata, } \text { A. inflata, } \\
\text { A. leptocarpa, A. lindleyi, A. spongiosa, } \\
\text { A. semilunalaris, } \text { A. hortensis }\end{array}$ & $0.4 \mathrm{mM}$ & Total DW ${ }^{\mathrm{a}}$ & Brownell 1968 \\
\hline Atriplex nummularia and $A$. inflata & $\begin{array}{l}0.1 \text { and } \\
0.6 \mathrm{mM}\end{array}$ & $\begin{array}{l}\text { Shoot } \mathrm{FW}^{\mathrm{b}} \text {; leaf chlorophyll, } \\
\text { sugar, and starch concentration }\end{array}$ & Brownell and Jackman 1966 \\
\hline $\begin{array}{l}\text { Japanese millet (Echinochloa utilis), Bermuda } \\
\text { grass (Cynodon dactylon), Shortleaf spikesedge } \\
\text { (Kyllinga brevifolia), Joseph's-coat (Amaranthus } \\
\text { tricolor), Kochia childsii, Moss-rose (Portulaca } \\
\text { grandiflora) }\end{array}$ & $0.1 \mathrm{mM}$ & Total DW & Brownell and Crossland 1972 \\
\hline $\begin{array}{l}\text { Kochia childsii, Rhodes grass (Chloris gayana), } \\
\text { Amaranthus caudatus L. }\end{array}$ & $0.1 \mathrm{mM}$ & Total FW & Johnston et al. 1988 \\
\hline Joseph's-coat (Amaranthus tricolor L.) & $0.5 \mathrm{mM}$ & Growth rate & Ohta et al. 1987 \\
\hline $\begin{array}{l}\text { Maize (Zea mays L.), Barnyard grass (Echinochloa } \\
\text { crus-galli L.), Hog millet (Panicum miliaceum L.), } \\
\text { Kleingrass (Panicum coloratum L.), Panicum } \\
\text { dichotomiflorum, Panicum maximum, Rhodes } \\
\text { grass (Chloris gayana) }\end{array}$ & $0.1 \mathrm{mM}$ & Growth rate & Ohta et al. 1988 \\
\hline Joseph's-coat (Amaranthus tricolor L.) & $0.5 \mathrm{mM}$ & $\begin{array}{l}\mathrm{RGR}^{\mathrm{c}} \text {, nitrate reductase activity, } \\
\mathrm{O}_{2} \text { evolution, chlorophyll } \\
\text { content }\end{array}$ & Ohta et al. 1989 \\
\hline Tomato (Solanum lycopersicum L.) & $1 \mathrm{mM}$ & Total DW & Woolley 1957 \\
\hline
\end{tabular}

this may well relate to their ecological habit as ruderal, r-strategic, species (Desplanque et al. 1999), capable of substantial growth rates and physiological flexibility in response to rapidly changing environments. The ability to, opportunistically, utilize the $\mathrm{Na}^{+}$ion when available, as an osmoticum to aid with rapid expansion growth (see later), may impart a significant competitive advantage in such potentially fast-growing species. Interestingly, many of the same species are also known to "luxury-consume" the $\mathrm{NO}_{3}{ }^{-}$ion when it is readily available, and accumulate it to high levels in particular in vacuoles, to the point that such levels are often considered a health hazard for human consumption, as, for instance, in spinach and beet (Phillips 1971; Stanford et al. 1977). The Chenopodiaceae are furthermore interesting in that they can benefit from $\mathrm{Na}^{+}$ even when $\mathrm{K}^{+}$is present at significant concentrations alongside it in the growth medium (Marschner 1995; Subbarao et al. 2003), i.e. they do not require $\mathrm{K}^{+}$ depletion before effects are seen. In other words, effects are not limited to those attributable to a "replacement" of $\mathrm{K}^{+}$.
A further group for which much information is available, since early work focusing especially on the saltbush Atriplex, is that of species that engage in the $\mathrm{C}_{4}$ habit of photosynthesis. The paradigm that $\mathrm{C}_{4}$ species benefit particularly substantially, and indeed in many, albeit not all, cases require $\mathrm{Na}^{+}$as an essential nutrient, is now widely accepted (Harmer and Benne 1945; Barbier and Chambannes 1951; Brownell and Wood 1957; Brownell 1965; Alekseev and Abdurakhamanov 1966; Brownell and Jackman 1966; Brownell and Crossland 1972; Marschner 1995; Pessarakli and Marcum 2000; Pessarakli 2001; Subbarao et al. 2003). Important exceptions include the leading $\mathrm{C}_{4}$ crops corn and sorghum, which have been shown not to benefit from $\mathrm{Na}^{+}$addition (Ohta et al. 1988; Ohnishi et al. 1990; Subbarao et al. 2003). In $\mathrm{C}_{4}$ species, it is thought that $\mathrm{Na}^{+}$facilitates the conversion of pyruvate into phosphoenolpyruvate (PEP), which occurs in mesophyll cells, prior to the Calvin cycle (Johnston et al. 1988). Johnston et al. found that, under conditions of $\mathrm{Na}^{+}$deficiency in the $\mathrm{C}_{4}$ species Amaranthus tricolor, the $\mathrm{C}_{3}$ metabolites alanine and 
Table 2 Survey of published studies that report $\mathrm{Na}^{+}$as a beneficial nutrient (macronutrient, $>1 \mathrm{mM}$ ) for some plant species

\begin{tabular}{|c|c|c|c|}
\hline Species & {$\left[\mathrm{Na}^{+}\right]_{\text {external }}$} & Measure(s) improved by $\mathrm{Na}^{+}$ & Reference \\
\hline Bladder saltbush (Atriplex vesicaria) & $0.04-1.2 \mathrm{mM}$ & Total $\mathrm{FW}^{\mathrm{a}}, \mathrm{DW}^{\mathrm{b}}$ & Brownell 1965 \\
\hline Bladder saltbush (Atriplex vesicaria) & $0.1-1.2 \mathrm{mM}$ & DW & Brownell and Wood 1957 \\
\hline Beet (Beta vulgaris L.) & $1-32 \mathrm{mM}$ & Shoot FW, DW; Root FW, DW & El-Sheikh et al. 1967 \\
\hline Suaeda aegyptiaca & $5-500 \mathrm{mM}$ & Shoot FW, DW; succulence & Eshel 1985 \\
\hline Cacao tree (Theobroma cacao) & $0.25-2 \mathrm{mM}$ & $\begin{array}{l}\text { Photosynthetic rate, } \mathrm{WUE}^{\mathrm{c}} \text {, mineral } \\
\text { nutrition }\end{array}$ & Gattward et al. 2012 \\
\hline Beet (Beta vulgaris L.) & $16 \mathrm{mM}$ & Water content, total FW & Lawlor and Milford 1973 \\
\hline Barley (Hordeum vulgare L.) & $8 \mathrm{mM}$ & Total DW & Mullison and Mullison 1942 \\
\hline Beet (Beta vulgaris L.) & $2-10 \mathrm{mM}$ & Leaf area and DW & Nunes et al. 1984 \\
\hline Atriplex portulacoides L. & $20-700 \mathrm{mM}$ & $\mathrm{RGR}^{\mathrm{d}}$ & Redondo-Gómez et al. 2007 \\
\hline Arthrocnemum macrostachyum & $171-510 \mathrm{mM}$ & RGR & Redondo-Gómez et al. 2010 \\
\hline $\begin{array}{l}\text { Lolium perenne L., Timothy (Phleum } \\
\text { pratense L.) }\end{array}$ & $1-13 \mathrm{mM}$ & Nitrate reductase activity & Smith et al. 1980 \\
\hline Beet (Beta vulgaris L.) & $\begin{array}{l}3.75- \\
4.90 \mathrm{mM}\end{array}$ & Leaf area and water content, total DW & Subbarao et al. $1999 b$ \\
\hline Beet (Beta vulgaris L.) & $1.7-3.5 \mathrm{mM}$ & Total DW & Truog et al. 1953 \\
\hline Ranger alfalfa (Medicago sativa L.) & $4 \mathrm{mM}$ & Total DW & Wallace et al. 1948 \\
\hline Halogeton glomeratus & $1-100 \mathrm{mM}$ & Width of lateral branches; total DW & Williams 1960 \\
\hline
\end{tabular}

${ }^{\text {a }}$ Fresh weight

${ }^{\mathrm{b}}$ Dry weight

${ }^{\mathrm{c}}$ Water-use efficiency

${ }^{\mathrm{d}}$ Relative growth rate

pyruvate increased, whereas central $\mathrm{C}_{4}$ metabolites, such as malate, aspartate, and PEP, decreased. In the $\mathrm{C}_{3}$ species tomato, by contrast, none of these metabolites was influenced by $\mathrm{Na}^{+}$(Johnston et al. 1988). Furthermore, in the $\mathrm{C}_{4}$ species Atriplex tricolor and Kochia childsii, when sodium-deficient, the activity of photosystem II (PS II), in mesophyll chloroplasts, was altered, whereas it remained unaffected in bundle-sheath chloroplasts (Johnston et al. 1989; Grof et al. 1989). Shoot nitrate assimilation is also confined to mesophyll cells in $\mathrm{C}_{4}$ species (Moore and Black 1979; Vaughn and Campbell 1988). As $\mathrm{Na}^{+}$is known to enhance nitrate uptake in roots and nitrate assimilation in leaves, as shown in Amaranthus tricolor (Ohta et al. 1989), this may serve as one contributor to the beneficial effects seen.

$\mathrm{Na}^{+}$-coupled pyruvate transport in chloroplasts: one solid role for $\mathrm{Na}^{+}$in $\mathrm{C}_{4}$ species

Sodium is known to influence $\mathrm{C}_{4}$ metabolism in several species in another significant way, by virtue of facilitation of pyruvate uptake into chloroplasts. This was first demonstrated physiologically in Panicum miliaceum, where pyruvate uptake into chloroplasts was found to be proportional to the concentrations of $\mathrm{Na}^{+}$supply, indeed following a $1: 1$ ratio for $\mathrm{Na}^{+}$:pyruvate in the transport function (Ohnishi and Kanai 1987). This suggested the existence of a $\mathrm{Na}^{+}$-dependent pyruvate cotransport system in chloroplasts, possibly driven by a light-stimulated, $\mathrm{H}^{+}$-coupled, $\mathrm{Na}^{+}$efflux pump (Ohnishi et al. 1990; Furumoto et al. 2011). Pyruvate is central to the $\mathrm{CO}_{2}$-concentrating mechanism in $\mathrm{C}_{4}$ species, and it serves as a precursor to several major biochemical pathways in all plants, such as fatty acid synthesis and isoprenoid metabolism; furthermore, as the end product of glycolysis, it is positioned at a key intersection point of both primary and secondary metabolism (Schwender et al. 2004). In $\mathrm{C}_{4}$ species engaging in the 'MEP' (methyl-erythritol-phosphate) pathway, pyruvate import into chloroplasts, across the envelope, is pivotal to the $\mathrm{C}_{4}$ habit, and it is specifically here where $\mathrm{Na}^{+}$-coupling is now established (Weber and von Caemmerer 2010). By contrast, at the functional level, the $\mathrm{Na}^{+}$-coupled mechanism is not found in chloroplasts of corn, offering at least a partial 
Table 3 Survey of published studies that report $\mathrm{Na}^{+}$as a beneficial nutrient for some plant species. Sodium concentrations in these studies were expressed as $\mathrm{kg} / \mathrm{ha}$ or $\mathrm{g} / \mathrm{kg}$ soil, but since field capacity of the soils were not specified, they cannot be compared directly with other studies

\begin{tabular}{|c|c|c|c|}
\hline Species & {$\left[\mathrm{Na}^{+}\right]_{\text {external }}$} & $\begin{array}{l}\text { Measure(s) improved by } \\
\mathrm{Na}^{+}\end{array}$ & Reference \\
\hline Eucalyptus grandis & $68 \mathrm{~kg} / \mathrm{ha}$ & $\begin{array}{l}\text { Tree height, basal area, } \\
\text { biomass }\end{array}$ & Almeida et al. 2010 \\
\hline Beet (Beta vulgaris L.) & $100-800 \mathrm{~kg} / \mathrm{ha}$ & Sugar yield & Draycott and Bugg 1982 \\
\hline Beet (Beta vulgaris L.) & $150 \mathrm{~kg} / \mathrm{ha}$ & Sugar yield & Draycott and Durrant 1976 \\
\hline Beet (Beta vulgaris L.) & $45-225 \mathrm{~kg} / \mathrm{ha}$ & Sugar yield & Draycott et al. 1970 \\
\hline Beet (Beta vulgaris L.) & $100 \mathrm{~kg} / \mathrm{ha}$ & Sugar yield & Durrant et al. 1974 \\
\hline Beet (Beta vulgaris L.) & $250 \mathrm{~kg} / \mathrm{ha}$ & $\begin{array}{l}\text { Water content, root } \mathrm{DW}^{\mathrm{a}} \text {, } \\
\text { sugar content }\end{array}$ & Durrant et al. 1978 \\
\hline Pangola grass (Digitaria eriantha) & 87 and $176 \mathrm{~kg} / \mathrm{ha}$ & DW & Gammon 1953 \\
\hline Beet (Beta vulgaris L.) & $30-90 \mathrm{~kg} / \mathrm{ha}$ & $\mathrm{FW}^{\mathrm{b}}$, water content & Haneklaus et al. 1998 \\
\hline $\begin{array}{c}\text { Beet (Beta vulgaris L.), Cabbage (Brassica } \\
\text { oleracea), Swiss chard (Beta vulgaris) }\end{array}$ & $560-1121 \mathrm{~kg} / \mathrm{ha}$ & Yield (FW) & Harmer and Benne 1945 \\
\hline $\begin{array}{l}\text { Celery (Apium graveolens), Beet (Beta } \\
\text { vulgaris L.), Wheat (Triticum aestivum L.), } \\
\text { Pea (Pisum sativum L.) }\end{array}$ & $280-1120 \mathrm{~kg} / \mathrm{ha}$ & Yield (FW) & Harmer et al. 1953 \\
\hline Cotton (Gossypium [species not specified]) & 129.92 or $163.52 \mathrm{~kg} / \mathrm{ha}$ & Total FW & Lancaster et al. 1953 \\
\hline $\begin{array}{l}\text { Beet (Beta vulgaris L.), Flax (Linum } \\
\text { usitatissimum L.), Oat (Avena sativa L.) }\end{array}$ & 49.28 and $98.56 \mathrm{~kg} / \mathrm{ha}$ & Total DW & Larson and Pierre 1953 \\
\hline $\begin{array}{l}\text { Oat (Avena sativa L.), Turnip (Brassica rapa } \\
\text { var. rapa), Potato (Solanum tuberosum L.), } \\
\text { Italian ryegrass (Lolium multiflorum) }\end{array}$ & $100-800 \mathrm{~kg} / \mathrm{ha}$ & Yield & Lehr 1950 \\
\hline Cotton (Gossypium [species not specified]) & $26.88,53.76$, and $80.64 \mathrm{~kg} / \mathrm{ha}$ & Total FW & Marshall and Sturgis 1953 \\
\hline Beet (Beta vulgaris L.) & $0.6 \mathrm{~g} / \mathrm{kg}$ soil & Total DW, succulence & Milford et al. 1977 \\
\hline Beet (Beta vulgaris L.) & $300 \mathrm{~kg} / \mathrm{ha}$ & Total FW & Szulc et al. 2010 \\
\hline Beet (Beta vulgaris L.) & $90-180 \mathrm{~kg} / \mathrm{ha}$ & Yield & Tinker 1965 \\
\hline
\end{tabular}

${ }^{\mathrm{a}}$ Dry weight

${ }^{\mathrm{b}}$ Fresh weight

explanation why only some $\mathrm{C}_{4}$ species rely on sodium as a nutrient (Ohnishi et al. 1990; Aoki et al. 1992; Weber and von Caemmerer 2010). Recently, in a benchmark study, Furumoto et al. (2011) characterized the $\mathrm{Na}^{+}-$ pyruvate cotransport mechanism at the molecular level, by identification of the BASS2 gene in Flaveria and Cleome, and showing the protein's localization to the chloroplast envelope and the facilitation of pyruvate influx. They showed widespread distribution of the gene across various plant groups, but also its absence, at the protein expression level, in corn, in agreement with the earlier physiological observations, and in keeping with the great diversity known to exist among $\mathrm{C}_{4}$ species (Weber and von Caemmerer 2010), and the multiple evolutionary origins of the trait (Langdale 2011; Sage et al. 2011; Williams et al. 2012). However, there now appears little doubt that the mechanism of $\mathrm{Na}^{+}$-dependent pyruvate transport is central to the $\mathrm{Na}^{+}$requirement in many $\mathrm{C}_{4}$ species. $\mathrm{Na}^{+}$-coupled transport systems are very common in animals and marine protists, and one wonders how much flexibility might exist in other transport systems that are normally coupled to $\mathrm{H}^{+}$gradients (Britto and Kronzucker 2005), to utilize $\mathrm{Na}^{+}$gradients under special circumstances. This possibility is suggested, for instance, by the demonstration, in heterologous systems, such as Xenopus oocytes (albeit not necessarily in planta; Walker et al. 1996; Box and Schachtman 2000), that $\mathrm{K}^{+}$ transporters of the HKT family, normally acting as uniporters or $\mathrm{H}^{+}$-coupled mechanisms, can undergo $\mathrm{Na}^{+}$coupling (Rubio et al. 1995; Haro et al. 2005). Another intriguing suggestion is that fluxes of both phosphate and nitrate might be coupled to the steep electrochemical potential gradient for $\mathrm{Na}^{+}$in the marine angiosperm Zostera marinus (Rubio et al. 2005). 
It is noteworthy to point out that the interest in understanding operation and optimization mechanisms, such as $\mathrm{Na}^{+}$-pyruvate cotransport, in $\mathrm{C}_{4}$ species is also of great importance as efforts are intensified to transfer the $\mathrm{C}_{4}$ habit to major $\mathrm{C}_{3}$ crops, such as rice (Furbank et al. 2009; Weber and von Caemmerer 2010).

HKT2 - entry portal for $\mathrm{Na}^{+}$at low external concentrations, and prerequisite for the ion's benefits?

If $\mathrm{Na}^{+}$can be readily beneficial in so many plant species and, associated with this, accumulate to significant concentrations in plant organelles and organs to levels similar to those of $\mathrm{K}^{+}$(Gattward et al. 2012; Schulze et al. 2012), there must be efficient pathways for its entry across root plasma membranes. Interestingly, despite considerable effort, entry paths for $\mathrm{Na}^{+}$into roots have not as yet been successfully identified at the molecular level across taxonomic groups (Munns and Tester 2008; Zhang et al. 2010; Kronzucker and Britto 2011; Cheeseman 2013), while a strong body of evidence has shown, at least in grasses, that one family of genes, HKT2 (formerly referred to as $H K T 1$, but the latter designation is now reserved for a group of $\mathrm{Na}^{+}$transporters believed to be predominantly involved in intra-plant $\mathrm{Na}^{+}$transfer from root to shoot; Sunarpi et al. 2005; Møller et al. 2009), encodes transporters that can transport $\mathrm{Na}^{+}$at substantial rates across root plasma membranes, especially when $\mathrm{K}^{+}$is limiting (Horie et al. 2001, 2011; Laurie et al. 2002; Munns and Tester 2008; Hauser and Horie 2010). This is instructive, given that $\mathrm{Na}^{+}$ benefits tend to be at their most pronounced when $\mathrm{K}^{+}$is in short supply, and, indeed, $\mathrm{Na}^{+}$can assume some of the functions of $\mathrm{K}^{+}$. Also of interest, however, is that HKT2 members appear to be absent in a great many plant species, including in the currently leading genetic model system Arabidopsis thaliana (Sunarpi et al. 2005; Munns and Tester 2008; Møller et al. 2009). Arabidopsis is a particularly interesting example in that it possesses only one gene from the entire HKT family, AtHKT1, and it has been suggested that this limited arsenal may be a common feature in dicotyledonous plants, while grasses typically have many members of both the HKT1 and HKT2 families. Haro et al. (2010), however, observed that, nevertheless, $\mathrm{K}^{+}$-deprivation-enhanced $\mathrm{Na}^{+}$accumulation, and highaffinity $\mathrm{Na}^{+}$uptake, were observed in 16 randomly chosen crop species, including dicotyledonous ones (e.g. sunflower, onion, and alfalfa), and concluded that, therefore, the molecular picture for $\mathrm{Na}^{+}$uptake, even in the "high-affinity" range, is more complex than merely involving members from the HKT2 group of transporters (e.g. HKT1 might yet be found to engage in primary uptake, as suggested previously in Arabidopsis; Rus et al. 2001; Kronzucker and Britto 2011). Only in rice, and the Aveneae and Triticeae tribes of the Poaceae family, has high-affinity uptake been definitively associated with HKT transporters (Haro et al. 2010). Thus, HKT (in particular HKT2) transporters may be validly discussed as probable candidates for high-affinity $\mathrm{Na}^{+}$transport that may form a molecular foundation for $\mathrm{Na}^{+}$benefits in grasses, while the search for molecular candidates mediating high-affinity $\mathrm{Na}^{+}$uptake in other species must be considered ongoing.

In this context, it is interesting to speculate on the importance of $\mathrm{Na}^{+} / \mathrm{K}^{+}$symport, which has been reported in several studies (Rubio et al. 1995; Spalding et al. 1999; Szczerba et al. 2008), as such a function could offer additional explanatory power for synergistic effects of co-provision of the two ions. However, only very limited (and misleading; see Haro et al. 2005) demonstrations of such a function outside heterologous expression systems, such as Xenopus oocytes and yeast cells, have thus far occurred (Rubio et al. 1995; Spalding et al. 1999; Haro et al. 2005). Other than these instances, little evidence for $\mathrm{Na}^{+}$-coupled $\mathrm{K}^{+}$uptake exists in terrestrial plants (Maathuis et al. 1996; RodríguezNavarro and Rubio 2006; Corratgé-Faillie et al. 2010; Schulze et al. 2012), although it may play a significant role in aquatic angiosperms and algae (Maathuis et al. 1996). A far more common observation is that $\mathrm{Na}^{+}$, at already modest (below-saline) concentrations, inhibits $\mathrm{K}^{+}$-influx systems, both in the high- and low-affinity transport ranges for $\mathrm{K}^{+}$ (Rains and Epstein 1967a, b, c; Cheeseman 1982; Jeschke 1982; Kochian et al. 1985; Benlloch et al. 1994; Schachtman and Schroeder 1994; Santa-María et al. 1997; Flowers and Hajibagheri 2001; Fuchs et al. 2005; Martínez-Cordero et al. 2005; Kronzucker et al. 2006, 2008; Nieves-Cordones et al. 2007; Wang et al. 2007), and can, additionally, stimulate $\mathrm{K}^{+}$efflux (Shabala et al. 2006; Britto et al. 2010; Coskun et al. 2013), thus depressing $\mathrm{K}^{+}$-utilization efficiency in a two-pronged fashion. 
Can $\mathrm{Na}^{+}$assume $\mathrm{K}^{+}$functions?

Despite its reputation as a toxic ion in the plant biology realm, from a physico-chemical perspective, $\mathrm{Na}^{+}$does not particularly stand out-it shares its basic chemical properties, and reactivities, with most of its alkali-metal (principal-quantum-number-one) peers, and, despite some differences in both hydrated and non-hydrated radii, is, in fact, quite similar to $\mathrm{K}^{+}$. It certainly does not possess inherent qualities that flag it as especially toxic in relation to biological matrices and processes, unlike, for instance, strongly Lewis-acidic metals, such as transition metals and heavy metals. Indeed, on account of its physico-chemical similarity to $\mathrm{K}^{+}$, a role for $\mathrm{Na}^{+}$as a generic, "benign" osmoticum in plant vacuoles is especially plausible and reasonable. However, differences in chaotropic and lyotropic properties of the two ions in terms of their effects on water and molecular structure, while controversial (Mancinelli et al. 2007; Galamba 2012), may yet emerge as important to toxicity manifestations in intracellular compartments (Cheeseman 2013), and as a foundation for the maintenance of a high cytosolic $\mathrm{K}^{+} / \mathrm{Na}^{+}$ratio, although this has not yet been investigated stringently. A good number of the studies listed in Tables 1, 2, and 3 supports this notion. For instance, in beet, a replacement of $95 \%$ of the plant's leaf-tissue $\mathrm{K}^{+}$ by $\mathrm{Na}^{+}$resulted in no measurable negative impact on osmotic potential (Subbarao et al. 1999b). It has, thus, been concluded that a near-complete replacement of $\mathrm{K}^{+}$ by $\mathrm{Na}^{+}$in its osmotic function is possible (Shabala and Mackay 2011a, b; Gattward et al. 2012). For other, nonosmotic functions of $\mathrm{K}^{+}$, replacement by $\mathrm{Na}^{+}$may, however, not be as easily achieved. From the perspective of biochemical functions, such as in the cytoplasm, poorly characterized as it remains (Cheeseman 2013), there is believed to be a rather strict requirement for $\mathrm{K}^{+}$, and a strong maintenance of its concentration (Britto and Kronzucker 2008); indeed, $\mathrm{K}^{+}$is considered essential for protein synthesis (Hall and Flowers 1973; Wyn Jones et al. 1979) and oxidative phosphorylation (Flowers 1974), both of which are equally inhibited by $\mathrm{Na}^{+}$in glycophytes and halophytes (Greenway and Osmond 1972). More generally, $\mathrm{K}^{+}$is considered essential for the functioning of 50-60 enzymes (Leigh and Wyn-Jones 1986). However, it has also been shown that, at the enzyme level, $\mathrm{Na}^{+}$can assume some of the roles of $\mathrm{K}^{+}$at least in several prominent instances, as, e.g., in the case of sucrose synthase (Nitsos and Evans 1969). The latter authors showed a requirement of some $50 \mathrm{mM} \mathrm{K}^{+}$ for the enzyme's optimal function, and found equimolar concentrations of $\mathrm{Na}^{+}$to be only $\sim 20 \%$ effective, but not inhibitory. Similarly, $\mathrm{NH}_{4}{ }^{+}, \mathrm{Rb}^{+}$, and $\mathrm{Cs}^{+}$were able to substitute for $\mathrm{K}^{+}$at $\sim 80 \%$ effectiveness. Thus, while not as effective as $\mathrm{K}^{+}$, it is not inconceivable that $\mathrm{Na}^{+}$, at modest cytosolic levels, such as those reported in some studies even under saline conditions (Carden et al. 2003), may aid enzyme function rather than inhibit it, as long as cytosolic $\mathrm{K}^{+}$concentration concurrently remains at a reasonable level (Kronzucker et al. 2008; and see Fig. 1). Thus, if high-uptake situations can be maintained for $\mathrm{Na}^{+}$, in particular under low

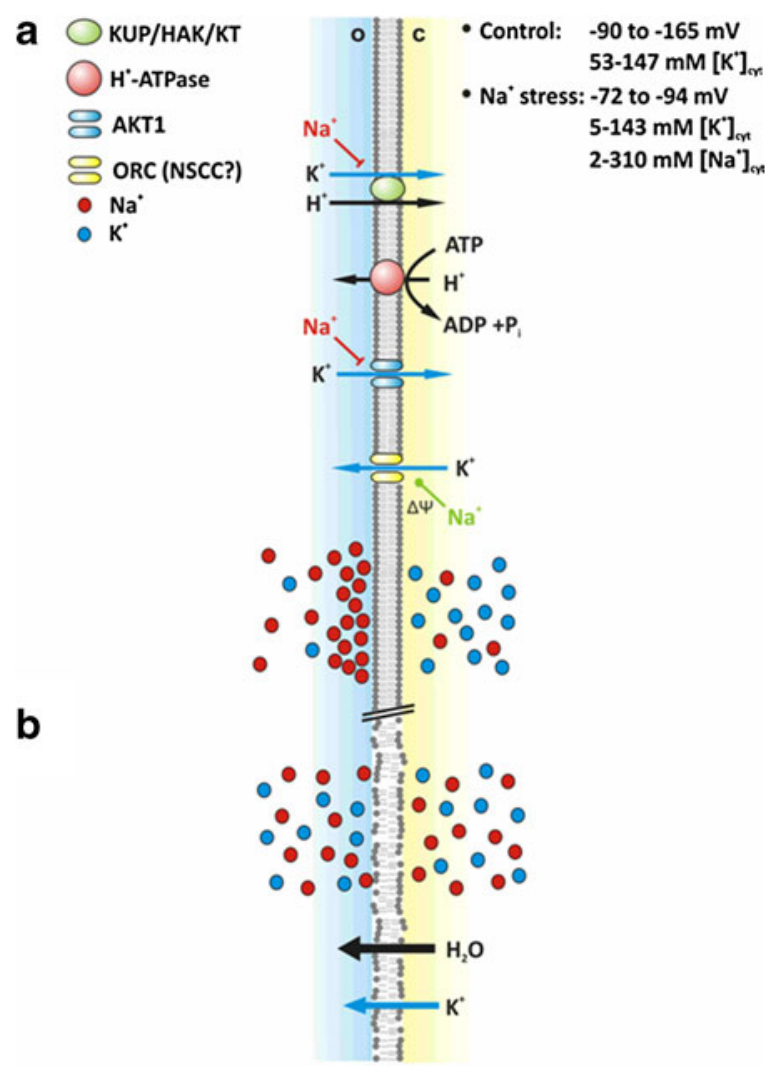

Fig. 1 Schematic illustration of the thermodynamics and mechanism of $\mathrm{K}^{+}$and $\mathrm{Na}^{+}$interactions at the plasma-membrane interface of plant roots. a Under non-osmotic challenges, $\mathrm{Na}^{+}$may inhibit (red) or stimulate (green) $\mathrm{K}^{+}$transport (blue arrows) (Santa-María et al. 1997; Thiel and Blatt 1991; Shabala et al. 2006). Cytsolic concentrations of $\mathrm{K}^{+}$and $\mathrm{Na}^{+}\left(\left[\mathrm{K}^{+}\right]_{\text {cyt }}\right.$ and $\left[\mathrm{Na}^{+}\right]_{\text {cyt }}$, respectively) and resting membrane potentials can alter with long-term $\mathrm{Na}^{+}$ stress (Hajibagheri et al. 1988; Flowers and Hajibagheri 2001; Carden et al. 2003; Kronzucker et al. 2006). b Sudden salinity stress can result in membrane disintegrity (osmotic shock) and the release of cellular contents, including $\mathrm{K}^{+}$and water (Nassery 1975; Cramer et al. 1985; Britto et al. 2010; Coskun et al. 2013) 
$\mathrm{K}^{+}$provision (but not complete deprivation; Evans and Sorger 1966), or when $\mathrm{K}^{+}$uptake is partially inhibited, including by $\mathrm{Na}^{+}$itself (see above, and Figs. 1 and 2), $\mathrm{Na}^{+}$may well "rise to the challenge" of filling in for $\mathrm{K}^{+}$in more than one of its key functions. In this context, it is also informative that several transport proteins, previously thought to be highly ion-specific, such as KUP/HAK/KT, AKT and NHX proteins, have been shown to engage in the transport of either $\mathrm{K}^{+}$and $\mathrm{Na}^{+}$under variable circumstances (Zhang and Blumwald 2001; Venema et al. 2002; Kronzucker and Britto 2011).

Can $\mathrm{Na}^{+}$replace $\mathrm{K}^{+}$in stomatal guard cells?

The mechanistic implications are not trivial

One specific subset of $\mathrm{K}^{+}$functions where $\mathrm{Na}^{+}$has received particular attention is the replacement of $\mathrm{K}^{+}$ in stomatal guard cells (Humble and Hsiao 1969;
Pallaghy 1968; Terry and Ulrich 1973; Jarvis and Mansfield 1980; Hampe and Marschner 1982; Véry et al. 1998; for review, see Robinson et al. 1997; Roelfsema and Hedrich 2005). This is to be regarded as a special case of replacement of $\mathrm{K}^{+}$in its osmotic role, affecting especially the vacuoles of guard cells. This stipulation is particularly interesting, given that highly $\mathrm{K}^{+}$-specific component mechanisms have been identified for both stomatal opening and closing, and large rates of ion flow must be established to facilitate prompt, and meaningful, stomatal response (see Fig. 2; Humble and Raschke 1971; Leonhardt et al. 1997; Schroeder et al. 1984, 1987; Schroeder 1988). Indeed, while some electrophysiological studies have shown that high $\mathrm{Na}^{+}$flux activity, in a domain similar to what is normally seen for $\mathrm{K}^{+}$, can be observed in guard cells (Zhao et al. 2011; cf. Schroeder et al. 1987; Schroeder 1988), current molecular-mechanistic models for stomatal function leave little room for

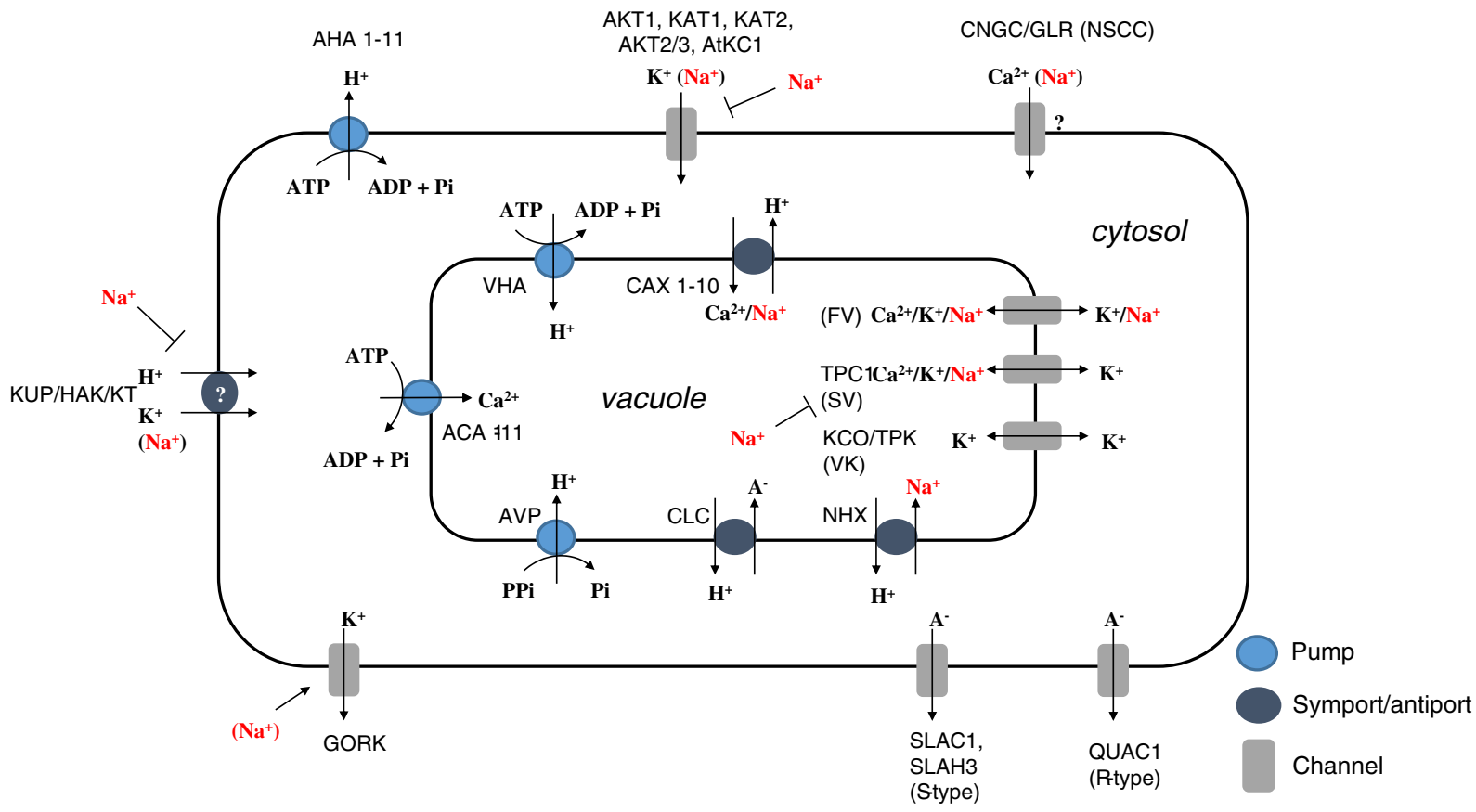

Fig. 2 Current model of ion transport in guard cells, highlighting $\mathrm{Na}^{+}$-specific mechanisms. $\mathrm{K}^{+}$influx channels (KAT1, KAT2, AKT1, AKT2/3, AtKC1; Pandey et al. 2007), integral to stomatal opening, can mediate $\mathrm{Na}^{+}$fluxes in some instances (Schroeder et al. 1987; Schroeder 1988; Obata et al. 2007), as can members of the KUP/HAK/KT family (Santa-María et al. 1997; Takahashi et al. 2007), although their involvement in guard cell functioning is currently speculative. Moreover, both classes of transporters can be directly inhibited by $\mathrm{Na}^{+}$(Fu and Luan 1998; Thiel and Blatt 1991). Non-selective cation channels (NSCCs) can also mediate
$\mathrm{Na}^{+}$fluxes (Zhao et al. 2011), although their molecular/genetic characterization is currently unknown. At the tonoplast, $\mathrm{Na}^{+}$ sequestration is linked to cation exchangers (CAX and NHX; Zhao et al. 2008; Apse et al. 2003) and vacuolar channels (SV and FV; Ivashikina and Hedrich 2005; Isayenkov et al. 2010). $\mathrm{SV}$ channels are also blocked by luminal $\mathrm{Na}^{+}$(Ivashikina and Hedrich 2005). $\mathrm{K}^{+}$efflux via channels (GORK; Hosy et al. 2003), critical to stomatal closing, can be stimulated by $\mathrm{Na}^{+}$ indirectly, via membrane depolarization (Shabala et al. 2006) 
$\mathrm{Na}^{+}$, and, to postulate its involvement, necessitates that one step outside the box of established thought.

As Fig. 2 illustrates, the entry of $\mathrm{K}^{+}$into guard cells, to facilitate stomatal opening, requires the engagement of potassium channels from the Shaker family (Schroeder et al. 1984, 1987; Schroeder 1988; Thiel et al. 1992; for review, see Schroeder et al. 2001; Pandey et al. 2007). The Nobel-Prize-winning work on Shaker channels has furthermore provided a model, based on $\mathrm{X}$-ray crystallography, of $\mathrm{K}^{+}$binding on the outside of the channel that specifically disallows the binding of $\mathrm{Na}^{+}$- according to the model, the ions are bound in their "naked", dehydrated state, and the difference in ionic radii makes it impossible for the smaller $\mathrm{Na}^{+}$ion to bind successfully to the oxygen-enriched "corners" of the channel (Doyle et al. 1998; Dreyer and Uozumi 2011). This model is supported by electrophysiological studies on guard cell protoplasts that demonstrate channel conductances with high (more than an order of magnitude larger) $\mathrm{K}^{+}$selectivity over $\mathrm{Na}^{+}$(Schroeder et al. 1984, 1987; Schroeder 1988; Blatt 1992; MüllerRöber et al. 1995; Nakamura et al. 1995; Véry et al. 1995; see also Véry et al. 1998; Lebaudy et al. 2008). However, given the multiplicity of inward-rectifying $\mathrm{K}^{+}$ channels being expressed in guard cells (Szyroki et al. 2001), and that some of these have been demonstrated to be capable of mediating $\mathrm{Na}^{+}$fluxes, albeit mostly in other cell types (Golldack et al. 2003; Obata et al. 2007; Wang et al. 2007), routes for high-capacity $\mathrm{Na}^{+}$ entry might exist under some conditions that are not currently accounted for in stomatal guard cell models (Fig. 2). Other such possible routes include nonselective cation channels (NSCCs), such as the cyclic nucleotide gated (CNGC) and/or glutamate receptor (GLR) channels (Lemtiri-Chlieh and Berkowitz 2004; Meyerhoff et al. 2005; Wolf et al. 2005; Zhao et al. 2011; see also Véry et al. 1998; Tyerman and Skerrett 1999). It is also possible that members of the KUP/HAK/KT family, generally attributed to primary $\mathrm{K}^{+}$uptake in roots (Gierth and Mäser 2007), might contribute, as these have been shown to be capable of mediating low-affinity $\mathrm{Na}^{+}$fluxes in roots under special circumstances (Santa-María et al. 1997; Takahashi et al. 2007; see also Mäser et al. 2002), and are also expressed in shoots (Kim et al. 1998; Rubio et al. 2000; Bañuelos et al. 2002; Su et al. 2002). However, a specific demonstration in guard cell opening and closing has not been made in any study of which we are aware. At the tonoplast, vacuolar sequestration of $\mathrm{Na}^{+}$has been attributed to the function of $\mathrm{Na}^{+} / \mathrm{H}^{+}$exchangers (NHX; Blumwald and Poole 1985; Apse et al. 1999, 2003) and both slow-vacuolar (SV) (Hedrich and Neher 1987; Schönknecht et al. 2002; Ivashikina and Hedrich 2005) and fast-vacuolar (FV) channels (Isayenkov et al. 2010). It has further been suggested that members of the cation exchanger (CAX) family could transport $\mathrm{Na}^{+}$(Luo et al. 2005; see also Zhao et al. 2008), but, again, none of these candidates is a part of current models of guard cell function. No leading reviews or textbook treatises on stomatal guard cell function have incorporated these flexibilities and, instead, they make the case for very specific, and central, engagement of $\mathrm{K}^{+}$ channels/transporters as integrated into a tightly orchestrated cascade of events, involving hormone binding, $\mathrm{Ca}^{2+}$ fluxes, and membrane potential activation of $\mathrm{K}^{+}$ fluxes (Schroeder et al. 2001). This, when combined with established molecular channel models that predict strict exclusion of $\mathrm{Na}^{+}$in particular for Shaker channels (Doyle et al. 1998; Dreyer and Uozumi 2011; cf. Obata et al. 2007; Zhao et al. 2011), poses profoundly interesting questions both about physiological plasticities and the applicability of strict molecular-mechanistic paradigms.

In addition to mediating $\mathrm{Na}^{+}$fluxes, several guard cell transporters are affected, either directly or indirectly, and usually negatively, by sodium's presence, particularly at higher concentrations (see below). Lastly, $\mathrm{K}^{+}$efflux via outward-rectifying $\mathrm{K}^{+}$channels (e.g. GORK; Hosy et al. 2003) has been shown to be stimulated by sodium's depolarization effects at the plasma membrane, which could have adverse effects on cytosolic $\mathrm{K}^{+}$homeostasis (Shabala et al. 2006), and might, in turn, be expected to affect stomatal guard cell function negatively.

It is instructive that, in some cases, authors have reported superior stomatal performance in plants cultivated on high $\mathrm{Na}^{+} / \mathrm{K}^{+}$ratios than on $\mathrm{K}^{+}$alone (Marschner 1995), and improved water-use efficiency (Gattward et al. 2012), suggesting that $\mathrm{Na}^{+}$may not only fill in for $\mathrm{K}^{+}$in the specific context of stomatal guard cell function, but may indeed be capable of outperforming it. We believe, in the light of the established model for stomatal function shown in Fig. 2, this warrants detailed attention at the mechanistic level, with potential for intriguing, and indeed paradigm-shifting, insights into membrane transporter function. Of further interest is the relationship between such transport activities and the tendency of some halophytes to reduce stomatal aperture in response to $\mathrm{Na}^{+}$supply, while some non- 
halophytes do the opposite (Robinson et al. 1997; Véry et al. 1998).

\section{Sodium toxicity}

The potassium target

A large number of studies has shown the disruption of both cellular and whole-plant potassium homeostasis under sodium stress (Rains and Epstein 1967a, b, c; Flowers and Läuchli 1983; Watad et al. 1991; Gaxiola et al. 1992; Warne et al. 1996; Zhu et al. 1998; SantaMaria and Epstein 2001; Peng et al. 2004; Cakmak 2005; Kader and Lindberg 2005; Kronzucker et al. 2006; Takahashi et al. 2007; Kronzucker et al. 2008; Britto et al. 2010; Coskun et al. 2013, cf. Seemann and Critchley 1985). Potassium homeostasis is critical for proper cell function, and one might ask, applying the "lex parsimoniae" principle of William of Ockham, whether its disruption by $\mathrm{Na}^{+}$may perhaps be sufficient to explain a large part of $\mathrm{Na}^{+}$toxicity. It is common in complex toxicological syndromes to invoke a large number of causes, or confound causes and their effects. Manifold as the effects of $\mathrm{Na}^{+}$on critical processes such as photosynthesis, transpiration, production of reactive oxygen species and, ultimately, growth and yield, are (Bazihizina et al. 2012; Cheeseman 2013), many, if not most, of these must be considered as downstream effects rather than primary causes of toxicity. There is no doubt that $\mathrm{Na}^{+}$, when appearing suddenly at high concentrations, in "shock" scenarios (see discussion in Cheeseman 2013), carries osmotic consequences that disrupt, typically temporarily, the membrane integrity of roots (Britto et al. 2010; Coskun et al. 2013), or also those of shoots, such as shown in rice (Flowers et al. 1991), preceding, or perhaps coinciding with, more "ion-specific" effects (see later discussions). In addition to this well-recognized osmotic effect, a second parsimonious explanation may lie in the disruption of potassium homeostasis - one that may reasonably and fruitfully supplant alternative, to date ill-substantiated (Kronzucker and Britto 2011), hypotheses, such as those of "toxic" $\mathrm{Na}^{+}$fluxes or cytosolic $\mathrm{K}^{+} / \mathrm{Na}^{+}$ratios (Maathuis and Amtmann 1999; Davenport and Tester 2000; Yao et al. 2010; see below). The decline in cytosolic $\left[\mathrm{K}^{+}\right]\left(\left[\mathrm{K}^{+}\right]_{\text {cyt }}\right)$ under saline conditions is well documented (Hajibagheri et al. 1987, 1988; Binzel et al. 1988; Schroeppel-Meier and
Kaiser 1988; Speer and Kaiser 1991; Hajibagheri and Flowers 2001; Carden et al. 2003; Kronzucker et al. 2006; see also Fig. 1) and is attributable to sodium's effects on $\mathrm{K}^{+}$transport (Szczerba et al. 2008; Kronzucker and Britto 2011). $\mathrm{Na}^{+}$has been shown to suppress $\mathrm{K}^{+}$influx in both its high- and low-affinity ranges, particularly at millimolar concentrations (Cheeseman 1982; Jeschke 1982; Schachtman and Schroeder 1994; Rubio et al. 1995; Gassmann et al. 1996; Maathuis et al. 1996; Santa-María et al. 1997; Martínez-Cordero et al. 2005; Kronzucker et al. 2006, 2008; Nieves-Cordones et al. 2007). Some studies have reported only weak $\mathrm{Na}^{+}$effects (Epstein 1961; Epstein et al. 1963; see also Seemann and Critchley 1985), or even stimulations of $\mathrm{K}^{+}$influx by $\mathrm{Na}^{+}$(Rubio et al. 1995; Spalding et al. 1999), but such studies are in the minority. As pointed out earlier in this review, and powerfully by others (Walker et al. 1996), some conflicting data on this front most probably arise from differences in experimental approaches, in particular between heterologous expression systems, excised roots, and intact plants (Haro et al. 2010). Overall, there is now broad consensus that the predominant effect of $\mathrm{Na}^{+}$co-presence in $\mathrm{K}^{+}$-containing media is one of affecting $\mathrm{K}^{+}$homeostasis negatively (Kronzucker et al. 2008).

Figure 1 summarizes the key events that are expected to lead to compromised cytosolic $\mathrm{K}^{+}$homeostasis in typical root cells. $\mathrm{Na}^{+}$can directly inhibit high-affinity $\mathrm{K}^{+}$transporters of the KUP/HAK/KT family (SantaMaría et al. 1997; Quintero and Blatt 1997; Fu and Luan 1998; Senn et al. 2001) and Shaker-type $\mathrm{K}^{+}$channels (Thiel and Blatt 1991; Qi and Spalding 2004; Fuchs et al. 2005; Wang et al. 2007). Moreover, transcript abundances of both KUP/HAK/KT transporters ( $\mathrm{Su}$ et al. 2002; Nieves-Cordones et al. 2007) and Shaker-type $\mathrm{K}^{+}$channels (Su et al. 2001; Golldack et al. 2003; Pilot et al. 2003) can be affected negatively by $\mathrm{NaCl}$. In most cases, transport inhibition is believed to be mediated by $\mathrm{Na}^{+}$binding to the outside of carriers and channels (Szczerba et al. 2008), although, in the case of some Shaker-type channels, a mechanism has also been proposed whereby small concentrations of cytosolic $\mathrm{Na}^{+}$ (near $10 \mathrm{mM}$ ) can effect inhibition from the inside of the cell (Qi and Spalding 2004); such concentrations are considered easily attained (Carden et al. 2003; Kronzucker and Britto 2011). In addition, as pointed out previously, $\mathrm{K}^{+}$efflux via outward-rectifying channels has been shown to be stimulated by $\mathrm{Na}^{+}$-induced 
depolarization of the plasma membrane (Shabala et al. 2006; Fig. 1a), which could contribute to the decline in $\left[\mathrm{K}^{+}\right]_{\text {cyt }}$. Thus, a suppression of $\left[\mathrm{K}^{+}\right]_{\text {cyt }}$ is one of the clear consequences of sodium's actions (perhaps not necessitating the invoking of the miraculous powers of a "cytosolic $\mathrm{K}^{+} / \mathrm{Na}^{+}$ratio"), as is a depolarization of the plasma-membrane potential, both instantaneously, upon first exposure to $\mathrm{Na}^{+}$(Shabala et al. 2003, 2006; Mian et al. 2011; cf. Bowling and Ansari 1971, 1972; Cheeseman 1982; Nocito et al. 2002), and in the longer term (Malagoli et al. 2008) (Fig. 1a). Upon sudden, "shock", applications of higher concentrations of $\mathrm{Na}^{+}$, membrane disintegrity due to osmotic shock and ionic displacement (particularly of $\mathrm{Ca}^{2+}$ ), result in the release of cellular contents, including $\mathrm{K}^{+}$and water (Nassery 1975, 1979; Lynch and Läuchli 1984; Cramer et al. 1985; Britto et al. 2010; Coskun et al. 2013; Fig. 1b), offering an alternative, or additional, explanation of enhanced $\mathrm{K}^{+}$release under $\mathrm{Na}^{+}$exposure (Britto et al. 2010; Coskun et al. 2013). Combined, the above effects of impaired $\mathrm{K}^{+}$influx and enhanced efflux are expected to result in blockage of $\mathrm{K}^{+}$translocation to the shoot (Erdei and Kuiper 1979; Botella et al. 1997; Kronzucker et al. 2006; Munns and Tester 2008), with obvious consequences for downstream events such as photosynthesis and stomatal function.

Sodium accumulation: what is better-more or less?

Many studies (e.g. Schubert and Läuchli 1990; Cramer 1992; Schachtman and Munns 1992; Davenport and Tester 2000; Munns and Tester 2008; Møller and Tester 2007; Møller et al. 2009) have suggested that the excessive accumulation of $\mathrm{Na}^{+}$, particularly in shoot tissue, lies at the heart of its toxicity. Indeed, this notion has driven much investigation into the identification of transport systems that either catalyze primary $\mathrm{Na}^{+}$influx into the root (Davenport and Tester 2000; Essah et al. 2003), or its distribution within the plant (Møller et al. 2009), with the tantalizing prospect of conferring salt tolerance by genetically modifying the influx or localization of $\mathrm{Na}^{+}$. However, as we shall now discuss, evidence is mounting that the assumption that sodium accumulation must be causally linked with its toxicity is not always a safe one.

In the case of wheat (Triticum spp.), clearly negative correlations have been observed between $\mathrm{Na}^{+}$accumulation and growth (e.g. Schachtman and Munns 1992; Munns and James 2003). More recent work, however, has shown that there is considerable deviation from this simple picture. For example, Rajendran et al. (2009), who examined salt stress and accumulation in 12 varieties of Triticum monococcum, found that two of the four most salt tolerant varieties accumulated among the highest amounts of $\mathrm{Na}^{+}$in the fourth leaf (Rajendran et al. 2009); this contrasted starkly with the other two most tolerant varieties, which had the lowest $\mathrm{Na}^{+}$levels. Thus, within the most salt tolerant tertile for a single species of wheat, there was a three- to seven-fold variation in sodium content, indicating that the relationship between accumulation and tolerance is by no means straightforward. Similarly, in a recent large survey of bread wheat (Triticum aestivum) genotypes, there was no clear relationship between tissue $\mathrm{Na}^{+}$exclusion and salinity tolerance (Genc et al. 2007). Although it has been suggested that this was due to shoot $\mathrm{Na}^{+}$accumulation being below the toxicity threshold (Møller and Tester 2007), these levels were nevertheless far from negligible (100-300 $\mathrm{mg} \mathrm{kg}^{-1}$ ), and, more importantly, did reduce shoot dry matter, on average, by one-third compared to controls, and reduced total biomass and yield by $50 \%$. In the case of corn, increased influx and shoot accumulation of $\mathrm{Na}^{+}$has been linked to its toxicity in some studies (Schubert and Läuchli 1990; Cramer 1992), while Cramer et al. (1994) later showed that $\mathrm{Na}^{+}$ accumulation in the shoots of two varieties of hybrid corn did not reflect their relative salt tolerances, concluding that salinity-induced growth depression was primarily due to osmotic stress. Perhaps the most surprising study of this nature in the realm of cereal grasses (Yeo et al. 1990) was conducted in rice, a particularly salt-sensitive species. In this survey of 150 rice genotypes, shoot sodium concentrations accounted for only a small degree of variation in survival under saline conditions. This is surprising, given that one of the leading causes of $\mathrm{Na}^{+}$toxicity in rice is thought to be apoplastic bypass flow to the shoot (Flowers et al. 1991).

Because of the substantial work that has been done at both ecophysiological and molecular levels in Arabidopsis thaliana, it is instructive to consider the question of how $\mathrm{Na}^{+}$accumulation, particularly in the shoot, affects $\mathrm{Na}^{+}$tolerance in this model species. In a pioneering study on $\mathrm{Na}^{+}$transport and accumulation in A. thaliana, Essah et al. (2003) showed that, although A. thaliana plants grown under 60 -fold differences in external $\left[\mathrm{Ca}^{2+}\right]$ showed 6-fold differences in per-plant accumulation of $\mathrm{Na}^{+}$(and 4-fold differences in $\mathrm{Na}^{+}$ accumulation per gram root), there were no differences 
in biomass between them. More recently, screening of 12 A. thaliana accessions yielded two coastal populations with reduced AtHKT1 expression that apparently resulted in increased shoot $\mathrm{Na}^{+}$and, surprisingly, greater salt tolerance (Rus et al. 2006). In a followup study (Baxter et al. 2010), many more such salttolerant accessions displaying this "weak allele" at the AtHKT1; 1 locus were discovered, often in populations growing in close proximity to coastal areas. Another recent survey, comparing four ecotypes of $A$. thaliana, indicated no inverse relationship between shoot $\mathrm{Na}^{+}$ concentration and $\mathrm{Na}^{+}$tolerance (Jha et al. 2010).

Studies on $A$. thaliana mutations which confer salt tolerance or hypersensitivity also cast doubt on the concept of elevated tissue $\mathrm{Na}^{+}$being detrimental under salinity stress. For instance, Arabidopsis plants overexpressing the vacuolar $\mathrm{Na}^{+} / \mathrm{H}^{+}$antiporter AtNHX1 were able to thrive on $\mathrm{NaCl}$ concentrations as high as $200 \mathrm{mM}$, exhibiting far superior growth than the wild type while containing about $30 \%$ more $\mathrm{Na}^{+}$(Apse et al. 1999). Similarly, overexpression of $O s N H X 1$ in upland rice resulted in growth significantly higher than that of wild type, while at the same time displaying both increases in shoot $\mathrm{Na}^{+}$and decreases in root and shoot $\mathrm{K}^{+}$ (Chen et al. 2007). Overexpression of the HvHKT2;1 gene (whose product is implicated in sodium influx - see above) in young barley plants resulted in improved growth despite increased $\mathrm{Na}^{+}$uptake, translocation, and shoot accumulation (Mian et al. 2011). Conversely, disruption of the $\operatorname{sos} 1$ gene, which putatively encodes an efflux transporter for $\mathrm{Na}^{+}$(but which, importantly, is also implicated in xylem loading for root-to-shoot $\mathrm{Na}^{+}$transfer), has been shown to result in Arabidopsis plants that are over 20 times more saltsensitive than wild type, while accumulating as little as half the amount of tissue $\mathrm{Na}^{+}$(Ding and Zhu 1997).

While perhaps surprising given the emphasis on reduced $\mathrm{Na}^{+}$uptake and translocation being a key to improved salt tolerance, the above studies in Arabidopsis thaliana are consistent with others involving members of the Brassicaceae. Indeed, the salt-including habit of many species in this family has been documented as early as 1896 (von Marilaun 1896). In more recent times, He and Cramer (1993) investigated $\mathrm{K}^{+} / \mathrm{Na}^{+}$ratios in shoot tissue of six Brassica species, near relatives of Arabidopsis, and found that they bore no relation to salt tolerance, while Porcelli et al. (1995) showed that yields and shoot growth of Brassica napus plants were not correlated with tissue $\mathrm{K}^{+} / \mathrm{Na}^{+}$or $\mathrm{Ca}^{2+} / \mathrm{Na}^{+}$ratios.
In cases where improvements in growth under salinity are accompanied by increased shoot $\mathrm{Na}^{+}$content, the concept of "tissue tolerance" is often proposed. Tissue tolerance is currently interpreted as involving effective sequestration of $\mathrm{Na}^{+}$into vacuoles, via transporters such as NHX1, where it will not harm cytosolic functions (Apse et al. 1999; Munns and Tester 2008; Møller et al. 2009; Jha et al. 2010). In support of this idea, Jha et al. (2010) have shown that there is a positive relationship between salt tolerance and expression levels of AtAVP1, which encodes an $\mathrm{H}^{+}$-pumping pyrophosphatase that is likely to be critical in the vacuolar sequestration of $\mathrm{Na}^{+}$. In contrast to such studies, however, the survey of rice cultivars by Yeo et al. (1990; see above) indicated that there was no correlation between shoot $\mathrm{Na}^{+}$and tissue tolerance; moreover, tissue tolerance was negatively correlated with both plant survival and plant vigour. In any case, even when increased shoot $\mathrm{Na}^{+}$and increased salt tolerance occur together, the term "tissue tolerance" appears somewhat weak. Such plants not only appear to "tolerate" higher levels of $\mathrm{Na}^{+}$in their tissues, but increased sequestration may in fact be a net benefit in such instances, possibly conferring greater osmotic capacity upon cells having vacuoles enriched in sodium. In this respect, beneficial $\mathrm{Na}^{+}$-including processes in glycophytes under salt stress may operate as they do under benign conditions or in halophytes (see Section I). A more startling speculation that arises from this analysis is that engineering plants to reduce their uptake of $\mathrm{Na}^{+}$and/or its translocation to the shoot might not be an effective solution to the problem of salt stress; indeed, the reverse could be true in many instances. Until these accumulation issues are better resolved, the roles of $\mathrm{Na}^{+}$transporters in salt tolerance and toxicity will not be adequately understood. What is clear at this point is that salinity stress and tolerance is a complex, multi-faceted trait, and cannot be predicted by simple indicators such as $\mathrm{Na}^{+}$accumulation (Yeo et al. 1990; Møller and Tester 2007; Rajendran et al. 2009).

Osmotic and ionic effects: what is the difference?

Osmotic stresses due to the presence of high salt concentrations in both the rooting medium and plant cell walls have long been known to be the chief initial cause of sodium toxicity (Jennings 1976; Greenway and Munns 1980; Munns and Tester 2008). Severe reductions in extracellular water potentials due to high salt loads can produce rapid dehydration and consequent 
damage of cells, and the similarities between salt and drought stresses are remarkable (Munns 2002). In the case of rice, most, if not all, salt-induced damage in the leaves might be due to osmotic stresses caused by $\mathrm{Na}^{+}$ buildup in the leaf apoplast (the "Oertli hypothesis"; Flowers et al. 1991; Krishnamurthy et al. 2011). Less clear, however, are the mechanisms underlying the secondary, "ion-specific" aspects of salt stress (Munns et al. 1995). Studies investigating these aspects often compare plant responses to salt provision against isosmotic provisions of non-ionic compounds such as polyethylene glycol, but these cannot provide a distinction, for example, between ion-specific effects of $\mathrm{Na}^{+}$and $\mathrm{Cl}^{-}$or $\mathrm{K}^{+}$, or between $\mathrm{NaCl}$ and other salts. Instead, chemically distinct, but isosmotic, salt treatments must be used (Greenway and Munns 1980; Kingsbury and Epstein 1985; Tavakkoli et al. 2010). Another caveat of such work is that, since these effects occur over a longer time scale than osmotic effects, short-term experiments are not appropriate (Munns et al. 2005; Tavakkoli et al. 2010).

While most studies of this nature do reveal nonosmotic consequences of excessive salt accumulation, their results can vary widely among plant systems; for instance, $\mathrm{Na}^{+}$has been found to inhibit photosynthetic processes in cereals such as rice and wheat, while $\mathrm{Cl}^{-}$ appears to be the more important ion in fava bean, and woody perennials such as citrus and grapevine (Tavakkoli et al. 2010). In addition, it remains difficult to distinguish between ion-specific and strictly osmotic effects (Greenway and Munns 1980; Yadav et al. 2011). Moreover, little is known about the deleterious action of hyperaccumulating ions in vivo, particularly within the cell. By contrast, the harmful effects of $\mathrm{Na}^{+}$on the transport and accumulation of nutrient ions, particularly $\mathrm{K}^{+}$, is becoming very clear (see above), as reinforced by the recent finding that the $\mathrm{Na}^{+}$-specific effects in salinity-treated bean plants were impaired $\mathrm{K}^{+}$and $\mathrm{Ca}^{2+}$ nutrition, and stomatal regulation (Tavakkoli et al. 2010).

One reason why $\mathrm{Na}^{+}$-specific toxicity mechanisms within the cell are poorly understood is that there is little certainty regarding intracellular $\mathrm{Na}^{+}$concentrations, particularly in the cytosol. While the maintenance of a high $\mathrm{K}^{+} / \mathrm{Na}^{+}$activity ratio in the cytosol of plant root cells is frequently described in the literature as being a critical determinant of plant performance under salinity stress, direct evidence supporting this contention is, by comparison, extremely rare. While there is a strong consensus from independent lines of evidence that the cytosolic levels of $\mathrm{K}^{+}$in plant cells are typically around $100 \mathrm{mM}$ (Walker et al. 1996; Britto and Kronzucker 2008), measurements of cytosolic $\mathrm{Na}^{+}$differ dramatically from one another, depending on the methods used (Kronzucker and Britto 2011). This can be illustrated by comparing two studies examining the same pair of barley cultivars, one using X-ray microanalysis (Flowers and Hajibagheri 2001), the other using intracellular $\mathrm{Na}^{+}$specific electrodes (Carden et al. 2003); estimates from the two studies disagree from 4- to 90-fold (although it should be noted that different exposure times to elevated $\mathrm{NaCl}$ were used). Despite lack of consensus on this critical parameter, cytosolic $\mathrm{K}^{+} / \mathrm{Na}^{+}$ratios are frequently invoked as central to sodium toxicity. For instance, in what is perhaps the most highly influential review on this subject (cited over 300 times), Maathuis and Amtmann (1999) provide only three references to support the claim that "cytosolic levels of $\mathrm{Na}^{+}$in plant cells range from low millimolar levels to around $100 \mathrm{mM}$ ". One of these references is to a conference abstract (Carden et al. 1998), one to a study using the giant alga Acetabularia (Amtmann and Gradmann 1994, which reports values for $\left[\mathrm{Na}^{+}\right]_{\text {cyt }}$ of up to $300 \mathrm{mM}$ ), and the third reports estimates of cytosolic $\mathrm{K}^{+}$and $\mathrm{Cl}^{-}$using multiple methods, but does not contain any data on $\mathrm{Na}^{+}$(Hajibagheri et al. 1988). Despite the rather glaring lack of convincing measurements of cytosolic sodium, however, this and other similarly data-poor reviews continue to be cited in support of its presumed toxicological role.

Nevertheless, the issue of cytosolic $\mathrm{Na}^{+}$accumulation may yet prove important to explaining the causes of sodium toxicity. New experimental evidence supporting this connection might soon be achieved thanks to recent improvements in intracellular $\mathrm{Na}^{+}$-specific microelectrode technology. While not without pitfalls of their own (Carden et al. 2001), measurements with such electrodes are more direct and, perhaps, less afflicted by assumptions and technical problems than those using older methods such as compartmental analysis by tracer efflux (CATE) or X-ray microanalysis. X-ray microanalysis studies must contend with extraneous contributors to relevant spectral signals, low count rates, specimen instability, preparative artifacts, and determinations of cytosolic water content (Roomans 1988; Carden et al. 2003). CATE is often afflicted by the appearance of large tracer fluxes from poorly understood 
compartments, which, if erroneously identified as cytosolic, can yield extremely large artificial values of $\left[\mathrm{Na}^{+}\right]_{\text {cyt }}$ (Britto and Kronzucker 2012). Indeed, reported unidirectional $\mathrm{Na}^{+}$fluxes across the plasma membrane, as measured with CATE or with short-term tracer uptake experiments, appear at times to be too high to be energetically feasible (Britto and Kronzucker 2009). When coupled with even the small cytosolic exchange half-times for $\mathrm{Na}^{+}$found in the literature (Essah et al. 2003), these values can, with CATE, result in cytosolic $\left[\mathrm{Na}^{+}\right]$values an order of magnitude higher than those reported using electrodes (Kronzucker et al. 2006; see below). Perhaps because of uncertainties with these and other methods, ion-specific microelectrode measurements of cytosolic $\mathrm{Na}^{+}$accumulation have become the new standard (Munns and Tester 2008). Surprisingly, however, given that cytosolic $\left[\mathrm{Na}^{+}\right]$is considered to be a critical factor in $\mathrm{Na}^{+}$toxicity, very few studies have measured it using microelectrode technology (Carden et al. 2003; Rubio et al. 2005); clearly, much more progress needs to be made in this area.

The study by Rubio et al. (2005) is particularly striking as it was conducted in the marine angiosperm Zostera marina, and found only $10.7 \mathrm{mM}$ cytosolic $\mathrm{Na}^{+}$in an artificial seawater medium $\left(500 \mathrm{mM}\left[\mathrm{Na}^{+}\right]\right)$. Less of an extreme gradient was found by Carden et al. (2003) in barley seedlings exposed to $200 \mathrm{mM} \mathrm{NaCl}$, but here too the cytosolic $\mathrm{Na}^{+}$activity value was low, maximally, $29 \mathrm{mM}$. Interestingly, these are levels at which little enzyme inhibition occurs (Greenway and Osmond 1972; Munns and Tester 2008), so mechanisms of $\mathrm{Na}^{+}$-specific toxicity may need to be sought elsewhere. Of additional importance is the conundrum that these low values, relative to CATE and other methods, suggest that either unidirectional $\mathrm{Na}^{+}$fluxes reported across the membrane using tracers (Britto and Kronzucker 2009), or exchange half-times for cytosolic $\mathrm{Na}^{+}$pools (Essah et al. 2003), have been substantially overestimated. Another way to look at this problem is to predict cytosolic pool sizes on the basis of unidirectional influx across the plasma membrane and exchange halftimes for the cytosol (Cram 1969; MacRobbie 1971; Britto and Kronzucker 2001, 2003). If we use results from Essah et al. (2003) in an example, in which an exchange half-time of $5 \mathrm{~min}$ is endorsed (Cheeseman 1982), and a unidirectional influx of as high as $300 \mu \mathrm{mol} \mathrm{g}^{-1}$ (fresh wt) $\mathrm{h}^{-1}$ is reported (at $200 \mathrm{mM}$ external $\left[\mathrm{Na}^{+}\right]$; see their Fig. 2), a cytosolic concentration of $\mathrm{Na}^{+}$is predicted to be about $700 \mathrm{mM}$, more than two orders of magnitude higher than some reported microelectrode measurements at the same, or higher, external $\mathrm{Na}^{+}$concentrations (Carden et al. 2003; Rubio et al. 2005).

A novel aspect of ion-specific effects of $\mathrm{Na}^{+}$can be seen in work using extracellular ion-selective microelectrodes (e.g. Shabala et al. 2006). Here, a sudden provision of moderate to high $\mathrm{NaCl}$ has been shown to elicit a short-term $\mathrm{K}^{+}$efflux from the cell. However, radiotracer and tissue experiments have shown that, under higher $\mathrm{NaCl}$, there is a much more pronounced $\mathrm{K}^{+}$-loss effect over the long term, which has been attributed to osmotic, rather than ionic, $\mathrm{Na}^{+}$specific stresses (Britto et al. 2010; see above).

The role of membrane transporters

Several recent reviews have summarized the postulated mechanisms of $\mathrm{Na}^{+}$transport into, and out of, plant cells (Munns and Tester 2008; Zhang et al. 2010; Kronzucker and Britto 2011; Cheeseman 2013), and, yet, with only few exceptions, no consensus has emerged as to the actual relative in planta roles of the various components, and no molecular candidate has been convincingly identified for $\mathrm{Na}^{+}$influx under toxic conditions. The strongest agreement in the literature currently is that certain subclasses of nonselective cation channels (NSCCs), the voltageinsensitive VI-NSCCs, participate critically, and most of the evidence for this derives from electrophysiological studies, where evidence appears incontrovertible that NSCCs can conduct $\mathrm{Na}^{+}$currents (see summary in Kronzucker and Britto 2011). However, as we have previously pointed out, the relationship of currents obtained from such electrophysiological studies, mostly conducted in patch-clamp configurations in membrane patches and naked protoplasts, to $\mathrm{Na}^{+}$fluxes and accumulation at the whole-plant level has, by no means, been established, and many questions remain (Kronzucker and Britto 2011). Indeed, in planta fluxes in excess of 100 micromoles per gram (fresh weight) per hour have been repeatedly reported in root systems (Essah et al. 2003; Malagoli et al. 2008; Møller et al. 2009; Wang et al. 2009; Wetson and Flowers 2010), and one can show, using established models of cation transport and energization (Kronzucker et al. 2001; Britto and Kronzucker 2006), that ion fluxes of this magnitude, were they to indeed proceed across plasma membranes, would be associated with a respiratory 
energy cost vastly in excess of the entire respiratory budget of the plant (Malagoli et al. 2008; Britto and Kronzucker 2009; Kronzucker and Britto 2011).

Other transporters that have received attention as potential candidates for $\mathrm{Na}^{+}$influx into (in particular) roots cells in planta are the low-affinity cation transporter LCT1 (Schachtman et al. 1997; Amtmann et al. 2001), the high- and low-affinity (and, at times, dualaffinity) $\mathrm{K}^{+}$transporters from the KUP/HAK/KT and AKT families (Santa-María et al. 1997; Amtmann and Sanders 1999; Blumwald et al. 2000; Golldack et al. 2003; Zhang et al. 2010), and members from the HKT family. Those from the HKT1 subfamily are believed to operate mostly in regulating root-to-shoot $\mathrm{Na}^{+}$translocation (Sunarpi et al. 2005; Møller et al. 2009), while those from the HKT2 subfamily have been implicated in primary $\mathrm{Na}^{+}$influx at least at lower $\mathrm{Na}^{+}$concentrations and in grasses (Horie et al. 2001; Laurie et al. 2002; Munns and Tester 2008; Hauser and Horie 2010; Horie et al. 2011; see also Schulze et al. 2012). In addition, two $\mathrm{Na}^{+} / \mathrm{H}^{+}$antiport systems have been identified, one of which, SOS1, is believed to be responsible predominantly for $\mathrm{Na}^{+}$efflux at the plasma membrane (Shi et al. 2000), the other, NHX1, for $\mathrm{Na}^{+}$sequestration into the vacuole (Apse et al. 1999).

An interesting conundrum arises for modern biotechnologically oriented approaches, not only because the primary influx transporters are not yet known, but because it is, in fact, not clear whether more or less $\mathrm{Na}^{+}$ entry should be a desirable goal. As previous sections of this review show, many species benefit from inclusion rather than exclusion of $\mathrm{Na}^{+}$, including, or perhaps especially, under saline external conditions, and the $\mathrm{Na}^{+}$ion's inherent toxicity is, from a chemical perspective, to be regarded largely as a myth. Thus, were engineering efforts successful to produce plant lines with silenced or downregulated influx mechanisms, and/or overexpressed plasma-membrane efflux systems, the result may, in many genotypes, be less tolerance, not more. Only experiments can show what may occur, and one eagerly awaits these. However, fundamental current hypotheses in terms of the preference of $\mathrm{Na}^{+}$inclusion versus exclusion might be too simplistic. Additionally, as touched upon in an earlier section of this review, with respect to the role of membrane transporters in the development of salt toxicity, the application of William of Ockham's "lex parsimoniae" might guide a closer look at, for instance, sodium's established effects on other critical membrane transport systems, such as those mediating potassium influx and efflux, and, related to this, osmotic effects, before implicating additional paradigms such as those of "toxic sodium fluxes" or "cytosolic sodium toxicity" (Kronzucker and Britto 2011; Cheeseman 2013).

The supersession of organismal physiology: evolution or mistake?

One final word pertains to a recent trend in the plant sciences that may have, in our view, contributed to a lack of progress in several critical areas within the sodium field, that is the near-solitary focus on molecular approaches to answer outstanding research questions. The study of function has, by contrast, recently only received marginal attention, and, more frequently than not, has not occured in planta intacta, but instead in excised systems (e.g. Essah et al. 2003) or heterologous expression systems (e.g. Rubio et al. 1995), such as Xenopus oocytes, yeast, or Escherichia coli. Some of the caveats relating to this have been discussed by others (e.g. Haro et al. 2010), but have received insufficient hearing overall. Further, in some prominent cases, gene and function have indeed been treated as synonymous, even linguistically (Britto and Kronzucker 2011). A related issue is a lack of remembrance with regard to work conducted in the 1950s, $60 \mathrm{~s}, 70 \mathrm{~s}$, and $80 \mathrm{~s}$ (and even earlier), prior to the onset of the molecular age, which is in evidence with increasing frequency. Indeed, it is not unusual for older discoveries to be re-discovered, while much available context is missed by insufficient awareness of the older literature. Examples of this include the large body of literature on $\mathrm{Na}^{+}$as a nutrient (reviewed here), Emanuel Epstein's early work on the mechanisms of $\mathrm{Na}^{+}$transport (Rains and Epstein 1965, 1967a, b, c; by contrast, in the related area of $\mathrm{K}^{+}$research, Epstein's early kinetic studies form a pillar of the field), and the literature on $\mathrm{K}^{+}$loss under $\mathrm{Na}^{+}$stress (see Britto et al. 2010). In addition, a readiness to accept dogma without, in many cases, sufficient measurement, has, in our view, and that of others (Cheeseman 2013), afflicted the sodium field to an unusual extent. Two examples include the role of the "cytosolic $\mathrm{K}^{+} / \mathrm{Na}^{+}$ratio", for which few actual measurements exist and which is yet referred to in numerous publications in the field, and, secondly, the involvement of non-selective cation channels (NSCCs) in mediating futile $\mathrm{Na}^{+}$cycling under salinity conditions, which has, in reality, not as 
yet been demonstrated conclusively in intact plant systems (Kronzucker and Britto 2011). It would be unwise to endorse the sidelining of stringent physiological examination and critical analysis in the above areas. We suggest that the sodium research field would benefit from greater awareness of, and dialogue between, both historical and recent discoveries and divergent approaches that have been, and yet should be, brought to bear on the field's critical outstanding questions.

Similarly, discoveries in the genetics and physiology of $\mathrm{Na}^{+}$nutrition and toxicity should continually be related to the performance of plants in ecological and agro-ecological settings. The productivity of natural and man-made biological systems will increasingly be subjected to potential salinity hazards, and the knowledge of how $\mathrm{Na}^{+}$cycles through and interacts with plants, in both beneficial and deleterious ways, is critical to the understanding and management of these systems. Insights from the above discussions may thus guide future selection and breeding approaches in novel ways, by favouring $\mathrm{Na}^{+}$inclusion traits in species where this may be of benefit (e.g. Hordeum vulgare, or members of the Chenopodiaceae and Brassicaceae), rather than simply attempting to silence them. The paucity of success in producing salttolerant cultivars for many crops may in part relate to a lack of thorough, and critical, examination of leading paradigms about $\mathrm{Na}^{+}$exclusion and cytosolic toxicity; such a critical examination is indispensable if advances are to successfully transfer from scientific concept and the lab bench to the agricultural field.

Acknowledgments Funding for this review was generously provided by the Natural Sciences and Engineering Research Council of Canada (NSERC) and the Canada Research Chair (CRC) program.

\section{References}

Alekseev AM, Abdurakhamanov AA (1966) On the influence of ions of mineral nutrient salts on the state of the protoplasm of plant cells. Fiziol Rast 13:414-419

Allen MB, Arnon DI (1955) Studies on nitrogen-fixing bluegreen algae. I. growth and nitrogen fixation by Anabaena cylindrica Lemm. Plant Physiol 30:366-372

Almeida JCR, Laclau JP, de Moraes Gonçalves JL, Ranger J, Saint-André L (2010) A positive growth response to $\mathrm{NaCl}$ applications in Eucalyptus plantations established on Kdeficient soils. For Ecol Manag 259:1786-1795
Amtmann A, Gradmann D (1994) $\mathrm{Na}^{+}$transport in Acetabularia bypasses conductance of plasmalemma. J Membr Biol 139:117-125

Amtmann A, Sanders D (1999) Mechanisms of Na+ uptake by plant cells. Adv Bot Res 29:75-112

Amtmann A, Fischer M, Marsh EL, Stefanovic A, Sanders D, Schachtman DP (2001) The wheat cDNA LCT1 generates hypersensitivity to sodium in a salt-sensitive yeast strain. Plant Physiol 126:1061-1071

Aoki N, Ohnishi J, Kanai R (1992) 2 different mechanisms for transport of pyruvate into mesophyll chloroplasts of $\mathrm{C}_{4}$ plants-a comparative study. Plant Cell Physiol 33:805809

Apse MP, Aharon GS, Snedden WA, Blumwald E (1999) Salt tolerance conferred by overexpression of a vacuolar $\mathrm{Na}^{+} /$ $\mathrm{H}^{+}$antiport in Arabidopsis. Science 285:1256-1258

Apse MP, Sottosanto JB, Blumwald E (2003) Vacuolar cation/ $\mathrm{H}^{+}$exchange, ion homeostasis, and leaf development are altered in a T-DNA insertional mutant of AtNHX1, the Arabidopsis vacuolar $\mathrm{Na}^{+} / \mathrm{H}^{+}$antiporter. Plant J 36:229-239

Bañuelos MA, Garciadeblas B, Cubero B, Rodríguez-Navarro (2002) Inventory and functional characterization of the HAK potassium transporters of rice. Plant Physiol 130:784-795

Barbier G, Chambannes J (1951) Accumulation du sodium dans les racines de plantes. C R Acad Sci 232:1372-1374

Baxter I, Brazelton JN, Yu D, Huang YS, Lahner B, Yakubova E, Li Y, Bergelson J, Borevitz JO, Nordborg M, Vitek O, Salt DE (2010) A coastal cline in sodium accumulation in Arabidopsis thaliana is driven by natural variation of the sodium transporter AtHKT1;1. Plos Genet 6:1-8

Bazihizina N, Barrett-Lennard EG, Colmer TD (2012) Plant growth and physiology under heterogeneous salinity. Plant Soil 354:1-19

Benlloch M, Ojeda MA, Ramos J, Rodriguez-Navarro A (1994) Salt sensitivity and low discrimination between potassium and sodium in bean plants. Plant Soil 166:117-123

Binzel HL, Hess FD, Bressan RA, Hasegawa PM (1988) Intracellular compartmentation of ions in salt adapted tobacco cell. Plant Physiol 86:607-614

Blatt MR (1992) K $\mathrm{K}^{+}$channels of stomatal guard cells - characteristics of the inward rectifiers and its control by $\mathrm{pH}$. J Gen Physiol 99:615-644

Blumwald E, Poole RJ (1985) $\mathrm{Na}^{+} / \mathrm{H}^{+}$antiport in isolated tonoplast vesicles from storage issue of Beta vulgaris. Plant Physiol 78:163-167

Blumwald E, Aharon GS, Apse MP (2000) Sodium transport in plant cells. Biochem Biophys Acta 1465:140-151

Botella MA, Martinez V, Pardines J, Cerdá A (1997) Salinity induced potassium deficiency in maize plants. J Plant Physiol 150:200-205

Bowling DJF, Ansari AQ (1971) Evidence for a sodium influx pump in sunflower roots. Planta 98:323-329

Bowling DJF, Ansari AQ (1972) Control of sodium transport in sunflower roots. J Exp Bot 23:241-246

Box S, Schachtman DP (2000) The effect of low concentrations of sodium on potassium uptake and growth of wheat. Aust J Plant Physiol 27:175-182

Britto DT, Kronzucker HJ (2001) Can unidirectional influx be measured in higher plants? A mathematical approach using parameters from efflux analysis. New Phytol 150:37-47 
Britto DT, Kronzucker HJ (2003) Ion fluxes and cytosolic pool sizes: examining fundamental relationships in transmembrane flux regulation. Planta 217:490-497

Britto DT, Kronzucker HJ (2005) Nitrogen acquisition, PEP carboxylase, and cellular $\mathrm{pH}$ homeostasis: new views on old paradigms. Plant Cell Environ 28:1396-1409

Britto DT, Kronzucker HJ (2006) Futile cycling at the plasma membrane: a hallmark of low-affinity nutrient transport. Trends Plant Sci 11:529-534

Britto DT, Kronzucker HJ (2008) Cellular mechanisms of potassium transport in plants. Physiol Plant 133:637650

Britto DT, Kronzucker HJ (2009) Ussing's conundrum and the search for transport mechanisms in plants. New Phytol 183:243-246

Britto DT, Kronzucker HJ (2011) Genes do not form channels. Plant Soil 346:15-17

Britto DT, Kronzucker HJ (2012) Isotope techniques to study kinetics of $\mathrm{Na}^{+}$and $\mathrm{K}^{+}$transport under salinity conditions. Meths Mol Biol 913:389-398

Britto DT, Ebrahimi-Ardebili S, Hamam AM, Coskun D, Kronzucker HJ (2010) ${ }^{42} \mathrm{~K}$ analysis of sodium-induced potassium efflux in barley: mechanism and relevance to salt tolerance. New Phytol 186:373-384

Brownell PF (1965) Sodium as an essential micronutrient element for a higher plant (Atriplex vesicaria). Plant Physiol 40:460-468

Brownell PF (1968) Sodium as an essential micronutrient element for some higher plants. Plant Soil 28:161-164

Brownell PF, Crossland CJ (1972) The requirement for sodium as a micronutrient by species having the $\mathrm{C}_{4}$ dicarboxylic photosynthetic pathway. Plant Physiol 49:794-797

Brownell PF, Jackman ME (1966) Changes during recovery from sodium deficiency in Atriplex. Plant Physiol 41:617-622

Brownell PF, Nicholas DJD (1968) Some effects of sodium on nitrate assimilation and $\mathrm{N}_{2}$ fixation in Anabaena cylindrica. Plant Physiol 42:915-921

Brownell PF, Wood JG (1957) Sodium as an essential micronutrient element for Atriplex vesicaria, Heward. Nature 179:635-636

Cakmak I (2005) The role of potassium in alleviating detrimental effects of abiotic stresses in plants. J Plant Nutr Soil Sci 168:521-530

Carden DE, Walker DJ, Flowers TJ (1998) Root cell cytosolic ion differences between barley cultivars may contribute to salt tolerance. In: Abstracts of the 11th International Workshop on Plant Membrane Biology. The Society of Experimental Biology, 345

Carden DE, Diamond D, Miller AJ (2001) An improved $\mathrm{Na}^{+}-$ selective microelectrode for intracellular measurements in plant cells. J Exp Bot 52:1353-1359

Carden DE, Walker DJ, Flowers TJ, Miller AJ (2003) Singlecell measurements of the contributions of cytosolic $\mathrm{Na}^{+}$ and $\mathrm{K}^{+}$to salt tolerance. Plant Physiol 131:676-683

Cheeseman JM (1982) Pump-leak sodium fluxes in low salt corn roots. J Membr Biol 70:157-164

Cheeseman JM (2013) The integration of activity in saline environments: problems and perspectives. Funct Plant Biol. doi:10.1071/FP12285

Chen H, An R, Tang J-H, Cui XH, Hao F-S, Chen J, Wang XC (2007) Over-expression of a vacuolar $\mathrm{Na}^{+} / \mathrm{H}^{+}$antiporter gene improves salt tolerance in an upland rice. Mol Breeding 19:215-225

Cope JT, Bradfield R, Peech M (1953) Effect of sodium fertilization on yield and cation content of some field crops. Soil Sci 76:65-79

Corratgé-Faillie, Jabnoune M, Zimmermann S, Véry AA, Fizames C, Sentenac H (2010) Potassium and sodium transport in non-animal cells: the Trk/Ktr/HKT transporter family. Cell Mol Life Sci 67:2511-2532

Coskun D, Britto DT, Jean YK, Kabir I, Tolay I, Torun AA, Kronzucker HJ (2013) $\mathrm{K}^{+}$efflux and retention in response to $\mathrm{NaCl}$ stress do not predict salt tolerance in contrasting genotypes of rice (Oryza sativa L.). PLoS One 8:1-16

Cram WJ (1969) Short term influx as a measure of influx across the plasmalemma. Plant Physiol 44:1013-1015

Cramer GR (1992) Kinetics of maize leaf elongation II. Responses of a Na-excluding cultivar and a Na-including cultivar to varying $\mathrm{Na} / \mathrm{Ca}$ salinities. J Exp Bot 43:857-864

Cramer GR, Läuchli A, Polito VS (1985) Displacement of $\mathrm{Ca}^{2+}$ by $\mathrm{Na}^{+}$from the plasmalemma of root cells. Plant Physiol 79:207-211

Cramer GR, Alberico GJ, Schmidt C (1994) Salt tolerance is not associated with the sodium accumulation of 2 maize hybrids. Aust J Plant Physiol 21:675-692

Davenport RJ, Tester M (2000) A weakly voltage-dependent, nonselective cation channel mediates toxic sodium influx in wheat. Plant Physiol 122:823-834

Desplanque B, Boudry P, Broomberg K, Saumitou-Laprade P, Cuguen J, Van Dijk H (1999) Genetic diversity and gene flow between wild, cultivated and weedy forms of Beta vulargis L. (Chenopodiaceae), assessed by RFLP and microsatellite markers. Theor Appl Genet 98:1194-1201

Ding L, Zhu JK (1997) Reduced $\mathrm{Na}^{+}$uptake in the NaClhypersensitive sos 1 mutant of Arabidopsis thaliana. Plant Physiol 113:795-799

Doyle DA, Cabral JM, Pfuetzner RA, Kuo A, Gulbis JM, Cohen SL, Chait BT, MacKinnon R (1998) The structure of the potassium channel: molecular basis of $\mathrm{K}^{+}$conduction and selectivity. Science 280:69-77

Draycott AP, Bugg SM (1982) Response by sugarbeet to various amounts and times of application of sodium chloride fertilizer in relation to soil type. J Agric Sci 98:579-592

Draycott AP, Durrant MJ (1976) Response by sugar beet to potassium and sodium fertilizers, particularly in relation to soils containing little exchangeable potassium. J Agric Sci 87:105-112

Draycott AP, Marsh JAP, Tinker PBH (1970) Sodium and potassium relationships in sugar beet. J Agric Sci 74:568-573

Dreyer I, Uozumi N (2011) Potassium channels in plant cells. FEBS J 278:4293-4303

Durrant MJ, Draycott AP, Boyd DA (1974) The response of sugar beet to potassium and sodium fertilizers. J Agric Sci 83:427-434

Durrant MJ, Draycott AP, Milford GFJ (1978) Effect of sodium fertilizer on water status and yield of sugar beet. Ann Appl Biol 88:321-328

El-Sheikh AM, Ulrich A, Broyer TC (1967) Sodium and rubidium as possible nutrients for sugar beet plants. Plant Physiol 42:1202-1208

Epstein E (1961) Essential role of calcium in selective cation transport by plant cells. Plant Physiol 36:437-444 
Epstein E, Bloom AJ (2005) Inorganic components of plants. In: Mineral nutrition of plants: principles and perspectives, 2nd edn. Sinauer Associates, Inc., Massachusetts, pp 44-45

Epstein E, Elzam OE, Rains DW (1963) Resolution of dual mechanisms of potassium absorption by barley roots. Proc Natl Acad Sci U S A 49:684-692

Erdei L, Kuiper PJC (1979) Effect of salinity on growth, cation content, $\mathrm{Na}^{+}$uptake and translocation in salt-sensitive and salt-tolerant Plantago species. Physiol Plant 47:95-99

Eshel A (1985) Response of Suaeda aegyptiaca to $\mathrm{KCl}, \mathrm{NaCl}$, and $\mathrm{Na}_{2} \mathrm{SO}_{4}$ treatments. Physiol Plant 64:308-315

Essah PA, Davenport R, Tester M (2003) Sodium influx and accumulation in Arabidopsis. Plant Physiol 133:307-318

Evans HJ, Sorger GJ (1966) Role of mineral elements with emphasis on univalent cations. Annu Rev Plant Physiol $17: 47-76$

Flowers TJ (1974) Salt tolerance in Suaeda maritima (L) Dum. A comparison of mitochondria isolated from green tissues of Suaeda and Pisum. J Exp Bot 101:101-110

Flowers TJ, Colmer TD (2008) Salinity tolerance in halophytes. New Phytol 179:945-963

Flowers TJ, Hajibagheri MA (2001) Salinity tolerance in Hordeum vulgare ion concentrations in root cells of cultivars differing in salt tolerance. Plant Soil 231:1-9

Flowers TJ, Läuchli A (1983) Sodium versus potassium: substitution and compartmentation. In: Läuchli A, Bieleski RL (eds) Encyclopedia of plant physiology, new series, vol 15b, inorganic plant nutrition. Springer, Berlin, pp 651-681

Flowers TJ, Hajibagheri MA, Yeo AR (1991) Ion accumulation in the cell walls of rice plants growing under saline conditions - evidence for the Oertli hypothesis. Plant Cell Environ 14:319-325

Fu HH, Luan S (1998) AtKUP1: a dual-affinity $\mathrm{K}^{+}$transporter from Arabidopsis. Plant Cell 10:63-73

Fuchs I, Stolzle S, Ivanshikina N, Hedrich R (2005) Rice $\mathrm{K}^{+}$ uptake channel OsAKT1 is sensitive to salt stress. Planta 221:212-221

Furbank RT, von Caemmerer S, Sheehy J, Edwards G (2009) $\mathrm{C}_{4}$ rice: a challenge for plant phenomics. Funct Plant Biol 36:845-856

Furumoto T, Yamaguchi T, Ohshima-Ichie Y, Nakamura M, Tsuchida-Iwata Y, Shimamura M, Ohnishi J, Hata S, Gowik U, Westhoff P, Bräutigam A, Weber APM, Izui K (2011) A plastidial sodium-dependent pyruvate transporter. Nature 476:472-475

Galamba N (2012) Mapping structural perturbations of water in ionic solutions. J Phys Chem B 116:5242-5250

Galeev RR (1990) Application of sodium humate to potatoes. Kartofel' I Ovoshchi 2:12-13

Gammon N (1953) Sodium and potassium requirements of pangola and other pasture grasses. Soil Sci 76:81-90

Gassmann W, Rubio F, Schroeder JI (1996) Alkali cation selectivity of the wheat root high-affinity potassium transporter HKT1. Plant J 10:869-882

Gattward JN, Almeide AAF, Souza JO, Gomes FP, Kronzucker HJ (2012) Sodium-potassium synergism in Theobroma cacao: stimulation of photosynthesis, water-use efficiency and mineral nutrition. Physiol Plant 146:350-362

Gaxiola R, Delarrinoa IF, Villalba JM, Serrano R (1992) A novel and conserved salt-induced protein is an important determinant of salt tolerance in yeast. EMBO J 11:3157-3164
Genc Y, McDonald GK, Tester M (2007) Reassessment of tissue $\mathrm{Na}^{+}$concentration as a criterion for salinity tolerance in bread wheat. Plant Cell Environ 30:1486-1498

Gierth M, Mäser P (2007) Potassium transporters in plants - involvement in $\mathrm{K}^{+}$acquisition, redistribution and homeostasis. FEBS Lett 581:2348-2356

Golldack D, Quigley F, Michalowski CB, Kamasani UR, Bohnert HJ (2003) Salinity stress-tolerance and -sensitive rice (Oryza sativa L.) regulate AKT1-type potassium channel transcripts differently. Plant Mol Biol 51:71-81

Greenway H, Munns R (1980) Mechanisms of salt tolerance in non-halophytes. Annu Rev Plant Biol 31:149-190

Greenway H, Osmond CB (1972) Salt responses of enzymes from species differing in salt tolerance. Plant Physiol 49:256-259

Grinstein S, Rothstein A (1986) Mechanisms of the regulation of the $\mathrm{Na}^{+} / \mathrm{H}^{+}$exchanger. J Membr Biol 90:1-12

Grof CPL, Johnston M, Brownell PF (1989) Effect of sodium nutrition on the ultrastructure of chloroplasts of $\mathrm{C} 4$ plants. Plant Physiol 89:539-543

Hajibagheri MA, Flowers TJ (2001) Salinity tolerance in Hordeum vulgare: ion concentrations in root cells of cultivars differing in salt tolerance. Plant Soil 231:1-9

Hajibagheri MA, Harvey DMR, Flowers TJ (1987) Quantitative distribution within the root cells of salt-sensitive and salttolerant maize varieties. New Phytol 105:367-379

Hajibagheri MA, Flowers TJ, Collins JC, Yeo AR (1988) A comparison of the methods of X-ray microanalysis, compartmental analysis and longitudinal ion profiles to estimate cytoplasmic ion concentrations in two maize varieties. J Exp Bot 39:279-290

Hall JL, Flowers TJ (1973) Effect of salt on protein synthesis in halophyte Suaeda maritima. Planta 110:361-368

Hampe T, Marschner H (1982) Effect of sodium on morphology, water relations and net photosynthesis in sugar beet leaves. Z Pflanzenphysiol 108:151-162

Haneklaus S, Krudsen L, Schnug E (1998) Relationship between potassium and sodium in sugar beet. Commun Soil Sci Plant Anal 29:1793-1798

Harmer PM, Benne EJ (1945) Sodium as a crop nutrient. Soil Sci Soc Am J 60:137-148

Harmer PM, Benne EJ, Laughlin WM, Key C (1953) Factors affecting crop response to sodium applied as a common salt on Michigan muck soil. Soil Sci 76:1-17

Haro R, Bañuelos MA, Senn MAE, Barrero-Gil J, RodríguezNavarro A (2005) HKT1 mediates sodium uniport in roots: pitfalls in the expression of HKT1 in yeast. Plant Physiol 139:1495-1506

Haro R, Bañuelos MA, Rodríguez-Navarro A (2010) Highaffinity sodium uptake in land plants. Plant Cell Physiol 51:68-79

Harris L (1996) Concepts in zoology. Harper Collins, New York

Hauser F, Horie T (2010) A conserved primary salt tolerance mechanism mediated by HKT transporters: a mechanism for sodium exclusion and maintenance of high $\mathrm{K}+/ \mathrm{Na}+$ ratio in leaves during salinity stress. Plant Cell Environ 33: 552-565

He T, Cramer GR (1993) Salt tolerance of rapid-cycling Brassica species in relation to potassium-sodium ratio and selectivity at the whole plant and callus levels. J Plant Nutr 16:12631277 
Hedrich R, Neher E (1987) Cytoplasmic calcium regulates voltagedependent ion channels in plant vacuoles. Nature 329:833-836

Horie T, Yoshia K, Nakayama H, Yamada K, Oiki S, Shinmyo A (2001) Two types of HKT transporters with different properties of $\mathrm{Na}+$ and $\mathrm{K}+$ transport in Oryza sativa. Plant J 27:129-138

Horie T, Brodsky DE, Costa A, Kaneko T, Lo Schiavo F, Katsuhara M, Schroeder JI (2011) K+ transport by OsHKT2;4 transporter from rice (Oryza sativa) with atypical $\mathrm{Na}+$ transport properties and competition in permeation of $\mathrm{K}+$ over $\mathrm{Mg} 2+$ and $\mathrm{Ca} 2+$ ions. Plant Physiol 156:1493-1507

Hosy E, Vavasseur A, Mouline K, Dreyer I, Gaymard F, Poree F, Boucherez J, Lebaudy A, Bouchez D, Véry AA, Simonneau T, Thibaud JB, Sentenac H (2003) The Arabidopsis outward K ${ }^{+}$ channel GORK is involved in regulation of stomatal movements and plant transpiration. Proc Natl Acad Sci U S A 100:5549-5554

Humble GD, Hsiao TC (1969) Specific requirement of potassium for light-activated opening of stomata in epidermal strips. Plant Physiol 44:230-234

Humble GD, Raschke K (1971) Stomatal opening quantitatively related to potassium transport-evidence from electron probe analysis. Plant Physiol 48:447-453

Hylton LO, Ulrich A, Cornelius DR (1967) Potassium and sodium interrelations in growth and mineral content of Italian Ryegrass. Agron J 59:311-314

Isayenkov S, Isner JC, Maathuis FJM (2010) Vacuolar ion channels: roles in plant nutrition and signalling. FEBS Lett 584:19821988

Ivashikina N, Hedrich R (2005) $\mathrm{K}^{+}$currents through SV-type vacuolar channels are sensitive to elevated luminal sodium levels. Plant J 41:606-614

Jarvis RG, Mansfield TA (1980) Reduced stomatal response to light, carbon dioxide and abscisic acid in the presence of sodium ions. Plant Cell Environ 3:279-283

Jennings DH (1976) The effects of sodium chloride on higher plants. Biol Rev 51:453-486

Jeschke WD (1977) $\mathrm{K}+-\mathrm{Na}+$ selectivity in roots, localisation of selective fluxes and their regulation. In: Marre E, Ciferri O (eds) Regulation of cell membrane activities in plants. Elselvier, Amsterdam, pp 63-78

Jeschke WD (1982) Shoot-dependent regulation of sodium and potassium fluxes in roots of whole barley seedlings. $\mathrm{J}$ Exp Bot 33:601-618

Jha D, Shirley N, Tester M, Roy SJ (2010) Variation in salinity tolerance and shoot sodium accumulation in Arabidopsis ecotypes linked to differences in the natural expression levels of transporters involved in sodium transport. Plant Cell Environ 33:793-804

Johnston M, Grof CPL, Brownell PF (1988) The effect of sodium nutrition on the pool sizes of intermediates of the C4 photosynthetic pathway. Aust J Plant Physiol 15:749-760

Johnston M, Grof CPL, Brownell PF (1989) Chlorophyll a/b ratios and photosystem activity of mesophyll and bundle sheath fractions from sodium-deficient C4 plants. Aust J Plant Physiol 16:449-457

Judel G, Kuhn H (1975) Über die Wirkung einer Natriumdüngung zu Zuckerrüben bei guter Versorgung mit Kalium in Gefäßversuchen. Zucker 28:68-71

Kader MA, Lindberg S (2005) Uptake of sodium in protoplasts of salt-sensitive and salt-tolerant cultivars of rice, Oryza sativa L. determined by the fluorescent dye SBFI. J Exp Bot 56:3149-3158

Kim EJ, Kwak JM, Uozumi N, Schroeder JI (1998) AtKUP1: an Arabidopsis gene encoding high-affinity potassium transport activity. Plant Cell 10:51-62

Kingsbury RW, Epstein E (1985) Salt sensitivity in wheat. A case for specific ion toxicity. Plant Physiol 80:651-654

Kochian LV, Xin-Zhi J, Lucas WJ (1985) Potassium transport in corn roots. IV. characterization of the linear component. Plant Physiol 79:771-776

Krishnamurthy P, Ranathunge K, Nayak S, Schreiber L, Mathew MK (2011) Root apoplastic barriers block $\mathrm{Na}^{+}$transport to shoots in rice (Oryza sativa L.). J Exp Bot 62:4215-4228

Kronzucker HJ, Britto DT (2011) Sodium transport in plants: a critical review. New Phytol 189:54-81

Kronzucker HJ, Britto DT, Davenport RJ, Tester M (2001) Ammonium toxicity and the real cost of transport. Trends Plant Sci 6:335-337

Kronzucker HJ, Szczerba MW, Moazami-Goudarzi M, Britto DT (2006) The cytosolic $\mathrm{Na}^{+}: \mathrm{K}^{+}$ratio does not explain salinityinduced growth impairment in barley: a dual-tracer study using ${ }^{42} \mathrm{~K}^{+}$and ${ }^{24} \mathrm{Na}^{+}$. Plant Cell Environ 29:2228-2237

Kronzucker HJ, Szczerba MW, Schulze LM, Britto DT (2008) Non-reciprocal interactions between $\mathrm{K}^{+}$and $\mathrm{Na}^{+}$ions in barley. J Exp Bot 59:2793-2801

Lancaster JD, Andrews WB, Jones US (1953) Influence of sodium on yield and quality of cotton lint and seed. Soil Sci 76:29-40

Langdale JA (2011) $\mathrm{C}_{4}$ cycles: past, present, and future research on $\mathrm{C}_{4}$ photosynthesis. Plant Cell 23:3879-3892

Larson WE, Pierre WH (1953) Interaction of sodium and potassium on yield and cation composition of selected crops. Soil Sci Soc Am J 76:51-64

Laurie S, Feeney KA, Maathuis FJM, Heard PJ, Brown SJ, Leigh RA (2002) A role for HKT1 in sodium uptake by wheat roots. Plant J 32:139-149

Lawlor DW, Milford GFJ (1973) The effect of sodium on growth of water-stressed sugar-beet. Ann Bot 37:597-604

Lebaudy A, Vavasseur A, Hosy E, Dreyer I, Leonhardt N, Thibaud JB, Véry AA, Simonneau T, Sentenac H (2008) Plant adaptation to fluctuating environment and biomass production are strongly dependent on guard cell potassium channels. Proc Natl Acad Sci U S A 105:5271-5276

Lehr JJ (1941) The importance of sodium for plant nutrition I. Soil Sci 52:237-244

Lehr JJ (1950) Importance of sodium for plant nutrition: v. responses of crops other than beet. Soil Sci 72:157-166

Lehr JJ (1953) Sodium as a plant nutrient. J Sci Food Agric 4:460471

Lehr JJ, Wybenga JM (1955) Exploratory pot experiments on sensitiveness of different crops to sodium. Plant Soil 3:251-261

Leigh RA, Wyn-Jones RG (1986) Cellular compartmentation in plant nutrition: the selective cytoplasm and the promiscuous vacuole. Adv Plant Nutr 2:249-279

Lemtiri-Chlieh F, Berkowitz GA (2004) Cyclic adenosine monophosphate regulates calcium channels in the plasma membrane of Arabidopsis leaf guard and mesophyll cells. J Biol Chem 279:35306-35312

Leonhardt N, Marin E, Vavasseur A, Forestier C (1997) Evidence for the existence of a sulfonylurea-receptor- 
like protein in plants: modulation of stomatal movements and guard cell potassium channels by sulfonylureas and potassium channel openers. Proc Natl Acad Sci U S A 94:14156-14161

Luo GZ, Wang HW, Huang J, Tian AG, Wang YJ, Zhang JS, Chen SY (2005) A putative plasma membrane cation/proton antiporter from soybean confers salt tolerance in Arabidopsis. Plant Mol Biol 59:809-820

Lutgens FK, Tarbuck EJ (2003) Foundations of earth science. Pearson, New Jersey

Lynch J, Läuchli A (1984) Potassium transport in salt-stressed barley roots. Planta 161:295-301

Maathuis FJM (2007) Monovalent cation transporters; establishing a link between bioinformatics and physiology. Plant Soil 301:1-15

Maathuis FJM, Amtmann A (1999) $\mathrm{K}^{+}$nutrition and $\mathrm{Na}^{+}$toxicity: the basis of cellular $\mathrm{K}^{+} / \mathrm{Na}^{+}$ratios. Ann Bot 84:123-133

Maathuis FJM, Verlin D, Smith FA, Sanders D, Fernandez JA, Walker NA (1996) The physiological relevance of $\mathrm{Na}^{+}$coupled $\mathrm{K}^{+}$-transport. Plant Physiol 112:1609-1616

MacRobbie EAC (1971) Fluxes and compartmentation in plant cells. Annu Rev Plant Physiol 22:75-96

Magat SS, Goh KM (1990) Effect of chloride on fertilizers on ionic composition and cation-anion balance and ratio of fodder beet (Beta vulgaris L.) grown under field conditions. New Zealand J Agric Res 33:29-40

Malagoli P, Britto DT, Schulze LM, Kronzucker HJ (2008) Futile $\mathrm{Na}^{+}$cycling at the root plasma membrane in rice (Oryza sativa L.) - kinetics, energetics, and relation to salinity tolerance. J Exp Bot 59:4109-4117

Mancinelli R, Botti A, Bruni F, Ricci MA, Soper AK (2007) Hydration of sodium, potassium, and chloride ions in solution and the concept of structure maker/breaker. J Phys Chem B 111:13570-13577

Marschner H (1995) Mineral nutrition of higher plants. Academic, London

Marshall JG, Sturgis MB (1953) Effects of sodium fertilizers on yield of cotton. Soil Sci 76:75-80

Martínez-Cordero MA, Martínez V, Rubio F (2005) High-affinity $\mathrm{K}^{+}$uptake in pepper plants. Plant Mol Biol 56:413-421

Mäser P, Gierth M, Schroeder JI (2002) Molecular mechanisms of potassium and sodium uptake in plants. Plant Soil 247: 43-54

Meyerhoff O, Müller K, Roelfsema M, Latz A, Lacombe B, Hedrich R, Dietrich P, Becker D (2005) AtGLR3.4, a glutamate receptor channel-like gene is sensitive to touch and cold. Planta 222:418-427

Mian A, Oomen RJFJ, Isayenkov S, Sentenac H, Maathuis FJM, Véry AA (2011) Over-expression of an $\mathrm{Na}^{+}$and $\mathrm{K}^{+}$permeable HKT transporter in barley improves salt tolerance. Plant J 68:468-479

Milford GFJ, Cormack WF, Durrant MJ (1977) Effects of sodium chloride on water status and growth of sugar beet. J Exp Bot 28:1380-1388

Møller IS, Tester M (2007) Salinity tolerance of Arabidopsis: a good model for cereals? Trends Plant Sci 12:534-540

Møller IS, Gilliham M, Jha D, Mayo GM, Roy SJ, Coates JC, Haseloff J, Tester M (2009) Shoot $\mathrm{Na}+$ exclusion and increase salinity tolerance engineered by cell type-specific alteration of $\mathrm{Na}+$ transport in Arabidopsis. Plant Cell $21: 2163-2178$
Montasir AH, Sharoubeem HH, Sidrak GH (1966) Partial substitution of sodium for potassium in water cultures. Plant Soil 25:181-194

Moore R, Black CC (1979) Nitrogen assimilation pathways in leaf mesophyll and bundle sheath cells of $\mathrm{C} 4$ photosynthetic plants formulated from comparative studies with Digitaria sanguinalis (L.) Scop. Plant Physiol 64:309-313

Müller-Röber B, Ellenberg J, Provart N, Willmitzer L, Bush H, Becker D, Dietrich P, Hoth S, Hedrich R (1995) Cloning and electrophysiological analysis of KST1, an inward rectifying $\mathrm{K}^{+}$channel expressed in potato guard cells. EMBO J 14:2409-2416

Mullison WR, Mullison E (1942) Growth responses of barley seedlings in relation to potassium and sodium nutrition. Plant Physiol 17:632-644

Munns R (2002) Comparative physiology of salt and water stress. Plant Cell Environ 25:239-250

Munns R, James RA (2003) Screening methods for salinity tolerance: a case study with tetraploid wheat. Plant Soil 253:201-218

Munns R, Tester M (2008) Mechanisms of salinity tolerance. Annu Rev Plant Biol 59:651-681

Munns R, Schachtman DP, Condon AG (1995) The significance of a two-phase growth response to salinity in wheat and barley. Aust J Plant Physiol 22:561-569

Munns R, James RA, Lauchli A (2005) Increasing salt tolerance in monocotyledonous plants, with emphasis on wheat. Comp Biochem Phys A 141:S337

Nakamura RL, McKendree WL, Hirsch RE, Sedbrook JC, Gaber RF, Sussman MR (1995) Expression of an Arabidopsis potassium channel in guard cells. Plant Physiol 109:371-374

Nassery H (1975) The effect of salt and osmotic stress on the retention of potassium by excised barley and bean roots. New Phytol 75:63-67

Nassery H (1979) Salt-induced loss of potassium from plant roots. New Phytol 83:23-27

Nieves-Cordones M, Martínez-Cordero MA, Martínez V, Rubio F (2007) An NH4+ -sensitive component dominates high affinity $\mathrm{K}+$ uptake in tomato plants. Plant Sci 172:273-280

Nitsos RE, Evans HJ (1969) Effects of univalent cations on activity of particulate starch synthetase. Plant Physiol 44:1260-1266

Nocito FF, Sacchi GA, Cocucci M (2002) Membrane depolarization induces $\mathrm{K}^{+}$efflux from subapical maize root segments. New Phytol 154:45-51

Nunes MA, Dias MA, Correia M, Oliveira MM (1984) Further studies on growth and osmoregulation of sugar beet leaves under low salinity conditions. J Exp Bot 35:322-331

Obata T, Kitamoto HK, Nakamura A, Fukuda A, Tanaka Y (2007) Rice shaker potassium channel OsKAT1 confers tolerance to salinity stress on year and rice cells. Plant Physiol 144:1978-1985

Ohnishi J, Kanai R (1987) $\mathrm{Na}^{+}$-induced uptake of pyruvate into mesophyll chloroplasts of $\mathrm{a}_{4}$ plant, Panicum miliaceum. FEBS Lett 219:347-350

Ohnishi J, Flügge UI, Heldt HW, Kanai R (1990) Involvement of $\mathrm{Na}+$ in active uptake of pyruvate in mesophyll chloroplasts of some C4 plants. Plant Physiol 94:950-959

Ohta D, Matoh T, Takahashi E (1987) Early responses of sodium-deficient Amaranthus tricolor L. plants to sodium application. Plant Physiol 84:112-117 
Ohta D, Matsui J, Matoh T, Takahashi E (1988) Sodium requirement of monocotyledonous $\mathrm{C}_{4}$ plants for growth and nitrate reductase activity. Plant Cell Physiol 29:1429-1432

Ohta D, Yasuoka S, Matoh T, Takahashi E (1989) Sodium stimulates growth of Amaranthus tricolor L. plants through enhanced nitrate assimilation. Plant Physiol 89:1102-1105

Pallaghy CK (1968) Electrophysiogical studies in guard cells of tobacco. Planta 80:147-153

Pandey S, Zhang W, Assmann SA (2007) Roles of ion channels and transporters in guard cell signal transduction. FEBS Lett 581:2325-2336

Peck NH, van Buren JP, MacDonald GE, Hemmat H, Becker RF (1987) Table beet plant and canned root responses to Na, K, and $\mathrm{Cl}$ from soils and from applications of $\mathrm{NaCl}$ and $\mathrm{KCl}$. $\mathrm{J}$ Am Soc Hort Sci 112:188-194

Peng YH, Zhu YF, Mao YQ, Wang SM, Su WA, Tang ZC (2004) Alkali grass resists salt stress through high $\left[\mathrm{K}^{+}\right]$ and an endodermis barrier to $\mathrm{Na}^{+}$. J Exp Bot 55:939-949

Pessarakli M (2001) Handbook of plant and crop stress. Biol Plant 44:304-304

Pessarakli M, Marcum KB (2000) Growth responses and Nitrogen15 absorption of Distichlis under sodium chloride stress. ASACSSA-SSSA Annual Meetings, Minneapolis, Minnesota

Pessarakli M, Tucker TC (1985) Uptake of Nitrogen-15 by cotton under salt stress. Soil Sci Soc Am J 49:149-152

Phillips WEJ (1971) Naturally occurring nitrate and nitrite in foods in relation to infant methaemoglobinaemia. Food Comest Toxicol 9:219-228

Pilot G, Gaymard F, Mouline K, Cherel I, Sentenac H (2003) Regulated expression of Arabidopsis Shaker $\mathrm{K}^{+}$channel genes involved in $\mathrm{K}^{+}$uptake and distribution in the plant. Plant Mol Biol 51:773-787

Porcelli CA, Boem FHG, Lavado RS (1995) The K/Na and Ca/ $\mathrm{Na}$ ratios and rapeseed yield, under soil salinity or sodicity. Plant Soil 175:251-255

Qi Z, Spalding EP (2004) Protection of plasma membrane $\mathrm{K}^{+}$transport by the salt overly sensitive $1 \mathrm{Na}^{+}-\mathrm{H}^{+}$ antiporter during salinity stress. Plant Physiol 136:25482555

Quintero FJ, Blatt MR (1997) A new family of $\mathrm{K}^{+}$transporters from Arabidopsis that are conserved across phyla. FEBS Lett 415:206-211

Rains DW, Epstein E (1965) Transport of sodium in plant tissue. Science 148:1161

Rains DW, Epstein E (1967a) Sodium absorption by barley roots - role of dual mechanisms of alkali cation transport. Plant Physiol 42:314-318

Rains DW, Epstein E (1967b) Preferential absorption of potassium by leaf tissue of mangrove Avicennia marina - an aspect of halophytic competence in coping with salt. Aust J Biol Sci 20:847-857

Rains DW, Epstein E (1967c) Sodium absorption by barley roots - its mediation by mechanism 2 of alkali cation transport. Plant Physiol 42:319-323

Rajendran K, Tester M, Roy SJ (2009) Quantifying the three main components of salinity tolerance in cereals. Plant Cell Environ 32:237-249

Redondo-Gómez S, Mateos-Naranjo E, Davy AJ, FernándezMuñoz F, Castellanos EM, Luque T, Figueroa ME (2007) Growth and photosynthetic responses to salinity of the saltmarsh shrub Atriplex portulacoides. Ann Bot 100:555-563
Redondo-Gómez S, Mateos-Naranjo E, Figueroa ME, Davy AJ (2010) Salt stimulation of growth and photosynthesis in an extreme halophyte, Arthrocnemum macrostachyum. Plant Biol 12:79-87

Robinson MF, Véry AA, Sanders D, Mansfield TA (1997) How can stomata contribute to salt tolerance? Ann Bot 80:387-393

Rodríguez-Navarro A, Rubio F (2006) High-affinity potassium and sodium transport systems in plants. J Exp Bot 57:11491160

Roelfsema MRG, Hedrich R (2005) In the light of stomatal opening: new insights into 'the Watergate'. New Phytol 167:665-691

Roomans GD (1988) Quantitative X-Ray microanalysis of biological specimens. J Electr Micr Tech 9:19-43

Rubio F, Gassmann W, Schroeder JI (1995) Sodium-driven potassium uptake by the plant potassium transporter HKT1 and mutations conferring salt tolerance. Science 270:1660-1663

Rubio F, Santa-María GE, Rodríguez-Navarro A (2000) Cloning of Arabidopsis and barley cDNAs encoding HAK potassium transporters in root and shoot cells. Physiol Plant 109:34-43

Rubio L, Linares-Rueda A, García-Sánchez MJ, Fernández JA (2005) Physiological evidence for a sodium-dependent high-affinity phosphate and nitrate transport at the plasma membrane of leaf and root cells of Zostera marina L. J Exp Bot 56:613-622

Rus A, Yokoi S, Sharkhuu A, Reddy M, Lee BH, Matsumoto TK, Koiwa H, Zhu JK, Bressan RA, Hasegawa PM (2001) AtHKT1 is a salt tolerance determinant that controls $\mathrm{Na}^{+}$ entry into plant roots. Proc Natl Acad Sci U S A 98:1415014155

Rus A, Baxter I, Muthukumar B, Gustin J, Lahner B, Yakubova Y, Salt DE (2006) Natural variants of AtHKT1 enhance $\mathrm{Na}^{+}$accumulation in two wild populations of Arabidopsis. Plos Genet 2:1964-1973

Sage RF, Christin PA, Edwards EJ (2011) The $\mathrm{C}_{4}$ plant lineages of planet Earth. J Exp Bot 62:3155-3169

Santa-Maria GE, Epstein E (2001) Potassium/sodium selectivity in wheat and the amphiploid cross wheat X Lophopyrum elongatum. Plant Sci 160:523-534

Santa-María GE, Rubio F, Dubcovsky J, Rodríguez-Navarro A (1997) The HAK1 gene of barley is a member of a large gene family and encodes a high-affinity potassium transporter. Plant Cell 9:2281-2289

Schachtman DP, Munns R (1992) Sodium accumulation in leaves of Triticum species that differ in salt tolerance. Funct Plant Biol 19:331-340

Schachtman DP, Schroeder JI (1994) Structure and transport mechanism of a high-affinity potassium uptake transporter from higher-plants. Nature 370:655-658

Schachtman DP, Kumar R, Schroeder JI, Marsh EL (1997) Molecular and functional characterization of a novel lowaffinity cation transporter (LCT1) in higher plants. Proc Natl Acad Sci USA 94:11079-11084

Schönknecht G, Spoormaker P, Steinmeyer R, Brüggeman L, Ache P, Dutta R, Reintanz B, Godde M, Hedrich R, Palme $\mathrm{K}$ (2002) KCO1 is a component of the slow-vacuolar (SV) ion channel. FEBS Lett 511:28-32

Schroeder JI (1988) $\mathrm{K}^{+}$transport properties of $\mathrm{K}^{+}$channels in the plasma membrane of Vicia faba guard cells. J Gen Physiol 92:667-683 
Schroeder JI, Hedrich R, Fernandez JM (1984) Potassiumselective single channels in guard cell protoplasts of Vicia faba. Nature 312:361-362

Schroeder JI, Raschke K, Neher E (1987) Voltage dependence of $\mathrm{K}^{+}$channels in guard-cell protoplasts. Proc Natl Acad Sci U S A 84:4108-4112

Schroeder JI, Allen GJ, Hugouvieux V, Kwak JM, Waner D (2001) Guard cell signal transduction. Annu Rev Plant Physiol Mol Biol 52:627-658

Schroeppel-Meier G, Kaiser WM (1988) Ion homeostasis in chloroplasts under salinity and mineral deficiency. Plant Physiol 87:822-827

Schubert S, Läuchli A (1990) Sodium exclusion mechanisms at the root surface of two maize cultivars. Plant Soil 123:205-209

Schulze LM, Britto DT, Li M, Kronzucker HJ (2012) A pharmacological analysis of high-affinity sodium transport in barley (Hordeum vulgare L.): $\mathrm{a}^{24} \mathrm{~N}^{+} /{ }^{42} \mathrm{~K}^{+}$study. J Exp Bot 63:2479-2489

Schwender J, Goffman F, Ohlrogge JB, Shachar-Hill Y (2004) Rubisco without the Calvin cycle improves the carbon efficiency of developing green seeds. Nature 432:779-782

Seemann JR, Critchley C (1985) Effects of salt stress on the growth, ion content, stomatal behavior and photosynthetic capacity of salt-sensitive species, Phaseolus vulgaris L. Planta 2:151-162

Segen JC, Stauffer J (1998) The patient's guide to medical tests. Checkmark books, New York

Senn ME, Rubio F, Bañuelos MA, Rodríguez-Navarro (2001) Comparative functional features of plant potassium HvHAK1 and HvHAK2 transporters. J Biol Chem 276:44563-44569

Shabala S, Mackay AS (2011a) Ion transport in halophytes. In: Kader J, Delseny M (eds) Advances in botanical research. Academic, Massachusetts, pp 151-199

Shabala S, Mackay AS (2011b) Ion transport in halophytes. Adv Bot Res 57:151-199

Shabala S, Shabala L, van Volkenburgh E (2003) Effect of calcium on root development and root ion fluxes in salinised barley seedlings. Funct Plant Biol 30:507-514

Shabala S, Demidchik V, Shabala L, Cuin TA, Smith SJ, Miller AJ, Davies JM, Newman IA (2006) Extracellular $\mathrm{Ca}^{2+}$ ameliorates $\mathrm{NaCl}$-induced $\mathrm{K}^{+}$loss from Arabidopsis root and leaf cells by controlling plasma membrane $\mathrm{K}^{+}$-permeable channels. Plant Physiol 141:1653-1665

Shi HZ, Ishitami M, Kim CS, Zhu JK (2000) The Arabidopsis thaliana salt tolerance gene SOS1 encodes a putative $\mathrm{Na}^{+}$/ $\mathrm{H}^{+}$antiporter. Proc Natl Acad Sci U S A 97:6896-6901

Simonis W, Urbach W (1963) Über eine Wirkung von Natriumionen auf die Phosphataufnahme und die lichtabhängige Phosphorylierung von Ankistrodesmus braunii. Arch Mikrobiol 46:265-286

Smith GS, Middleton KR, Edmonds AS (1980) Sodium nutrition of pasture plants. II. effects of sodium chloride on growth, chemical composition and reduction of nitrate nitrogen. New Phytol 84:613-622

Spalding EP, Hirsch RE, Lewis DR, Qi Z, Sussman MR, Lew BD (1999) Potassium uptake supporting plant growth in the absence of AKT1 channel activity - inhibition by ammonium and stimulation by sodium. J Gen Physiol 113:909-918

Speer M, Kaiser WM (1991) Ion relations of symplastic and apoplastic space in leaves from Spinacia oleracea L. and Pisum sativum L. under salinity. Plant Physiol 97:990-997
Stanford G, Carter JN, Westermann DT, Meisinger JJ (1977) Residual nitrate and mineralizable soil nitrogen in relation to nitrogen uptake by irrigated sugar beets. Agron J 69:303-308

Su H, Golldack D, Katsuhara M, Zhao CS, Bohnert HJ (2001) Expression and stress-dependent induction of potassium channel transcripts in the common ice plant. Plant Physiol 125:604-614

Su H, Golldack D, Zhao C, Bohnert HJ (2002) The expression of HAK-type $\mathrm{K}^{+}$transporters is regulated in response to salinity stress in common ice plant. Plant Physiol 129:1482-1493

Subbarao GV, Mackowiak C, Wheeler RM (1999a) Recycling of $\mathrm{Na}$ in advanced life support: strategies based on crop production systems. Life Support Biosph Sci 6:153-160

Subbarao GV, Wheeler RM, Stutte GW, Levine LH (1999b) How far can sodium substitute for potassium in red beet? J Plant Nutr 22:1745-1761

Subbarao GV, Wheeler RM, Levine LH, Stutte GW (2001) Glycine betaine accumulation, ionic and water relations of red-beet at contrasting levels of sodium supply. J Plant Physiol 158:767-776

Subbarao GV, Ito O, Berry WL, Wheeler RM (2003) Sodium-a functional plant nutrient. Crit Rev Plant Sci 22:391-416

Sunarpi, Horie T, Motoda J, Kubo M, Yang H, Yoda K, Horie R, Chan WY, Leung HY, Hattori K, Konomi M, Osumi M, Yamagami M, Schroeder JI, Uozumi N (2005) Enhanced salt tolerance mediated by AtHKT1 transporter-induced $\mathrm{Na}^{+}$unloading from xylem vessels into xylem parenchyma cells. Plant J 44:928-938

Szczerba MW, Britto DT, Ali SA, Balkos KD, Kronzucker HJ (2008) $\mathrm{NH}_{4}^{+}$-stimulated and -inhibited components of $\mathrm{K}^{+}$ transport in rice (Oryza sativa L.). J Exp Bot 59:34153423

Szulc PM, Kobierski M, Kubicki K, Keutgen N (2010) The potential of sodium fertilization for sugarbeet production. Zuckerindustrie 135:721-724

Szyroki A, Ivashikina N, Dietrich P, Roelfsema MRG, Ache P, Reintanz B, Deeken R, Godde M, Felle H, Steinmeyer R, Palme K, Hedrich R (2001) KAT1 is not essential for stomatal opening. Proc Natl Acad Sci U S A 98:2917-2921

Takahashi E, Maejima K (1998) Comparative research on sodium as a beneficial element for crop plants. Mem Fac Agr Kinki Univ 31:57-72

Takahashi R, Nishio T, Ichizen N, Takano T (2007) Highaffinity $\mathrm{K}^{+}$transporter PhaHAK5 is expressed only in salt-sensitive reed plants and shows $\mathrm{Na}^{+}$permeability under $\mathrm{NaCl}$ stress. Plant Cell Rep 26:1673-1679

Tavakkoli E, Rengasamy P, McDonald GK (2010) High concentrations of $\mathrm{Na}^{+}$and $\mathrm{Cl}^{-}$ions in soil solution have simultaneous detrimental effects on growth of faba bean under salinity stress. J Exp Bot 61:4449-4459

Terry N, Ulrich A (1973) Effects of potassium deficiency on the photosynthesis and respiration of leaves of sugar beet under conditions of low sodium supply. Plant Physiol 51:1099-1101

Thiel G, Blatt MR (1991) The mechanism of ion permeation through $\mathrm{K}^{+}$channels of stomatal guard cells - voltage dependent block by $\mathrm{Na}^{+}$. J Plant Physiol 138:326-334

Thiel G, MacRobbie EAC, Blatt MR (1992) Membrane transport in stomatal guard cells: the importance of voltage control. J Membrane Biol 126:1-18 
Tinker PBH (1965) The effects of nitrogen, potassium and sodium fertilizers on sugar beet. J Agric Sci 65:207-212

Truog E, Berger KC, Attoe OJ (1953) Response of nine economic plants to fertilization with sodium. Soil Sci Soc Am J 76:41-50

Tyerman SD, Skerrett IM (1999) Root ion channels and salinity. Sci Hortic-Amsterdam 78:175-235

Ulrich A, Ohki K (1956) Chlorine, bromine and sodium as nutrients for sugar beet plants. Plant Physiol 31:171-181

Vaughn KC, Campbell WH (1988) Immunogold localization of nitrate reductase in maize leaves. Plant Physiol 88:1354-1357

Venema K, Quintero FJ, Pardo JM, Donaire JP (2002) The Arabidopsis $\mathrm{Na}^{+} / \mathrm{H}^{+}$exchanger AtNHX1 catalyzes low affinity $\mathrm{Na}^{+}$and $\mathrm{K}^{+}$transport in reconstituted liposomes. J Biol Chem 277:2413-2418

Véry AA, Gaymard F, Bosseux C, Sentenac H, Thibaud JB (1995) Expression of a cloned plant $\mathrm{K}^{+}$channel in Xenopus oocytes: analysis of macroscopic currents. Plant J 7:321-332

Véry AA, Robinson MF, Mansfield TA, Sander D (1998) Guard cell cation channels are involved in $\mathrm{Na}^{+}$-induced stomatal closure in a halophyte. Plant J 14:509-521

von Marilaun AK (1896) The natural history of plants. Blackie \& Son Ltd, London

Walker NA, Sanders D, Maathuis FJM (1996) High-affinity potassium uptake in plants. Science 273:977-978

Wallace A, Toth SJ, Bear FE (1948) Influence of sodium on growth and composition of ranger alfalfa. Soil Sci 65:477-486

Wang SM, Zhang JL, Flowers TJ (2007) Low-affinity $\mathrm{Na}^{+}$uptake in the halophyte Suaeda maritima. Plant Physiol 145:559-571

Wang CM, Zhang JL, Liu XS, Li Z, Wu GQ, Cai JY, Flowers TJ, Wang SM (2009) Puccinellia tenuiflora maintains a low $\mathrm{Na}^{+}$level under salinity by limiting unidirectional $\mathrm{Na}^{+}$ influx resulting in a high selectivity for $\mathrm{K}^{+}$over $\mathrm{Na}^{+}$. Plant Cell Environ 32:486-496

Warne TR, Hickok LG, Kinraide TB, Vogelien DL (1996) High salinity tolerance in the st12 mutation of Ceratopteris richardii is associated with enhanced $\mathrm{K}^{+}$influx and loss. Plant Cell Environ 19:24-32

Watad AEA, Reuveni M, Bressan RA, Hasegawa PM (1991) Enhanced net $\mathrm{K}^{+}$uptake capacity of $\mathrm{NaCl}$-adapted cells. Plant Physiol 95:1265-1269

Weber APM, von Caemmerer S (2010) Plastid transport and metabolism of $\mathrm{C}_{3}$ and $\mathrm{C}_{4}$ plants - comparative analysis and possible biotechnological exploitation. Curr Opin Plant Biol 13:257-265

Wetson AM, Flowers TJ (2010) The effect of saline hypoxia on growth and ion uptake in Suaeda maritima. Funct Plant Biol 38:1024-1025
Wheeler HJ, Adams GE (1905) Concerning the agricultural value of sodium salts. Rhode Island Agricultural Experiment Station, Kingston

Williams MC (1960) Effect of sodium and potassium salts on growth and oxalate content of Halogeton. Plant Physiol 35:500-509

Williams BP, Aubry S, Hibberd JM (2012) Molecular evolution of genes recruited into $\mathrm{C}_{4}$ photosynthesis. Trends Plant Sci $17: 213-220$

Wolf T, Guinot DR, Hedrich R, Dietrich P, Marten I (2005) Nucleotides and $\mathrm{Mg}^{2+}$ ions differentially regulate $\mathrm{K}^{+}$channels and non-selective cation channels present in cells forming the stomatal complex. Plant Cell Physiol 46:1682-1689

Woolley JT (1957) Sodium and silicon as nutrients for the tomato plant. Plant Physiol 1:317-321

Wyn Jones RG, Brady CJ, Speirs J (1979) Ionic and osmotic relations in plant cells. In: Laidman DL, Wyn Jones RG (eds) Recent advances in the biochemistry of cereals. Academic Press, New York, New York, pp 63-103

Yadav S, Irfan M, Ahmad A, Hayat S (2011) Causes of salinity and plant manifestations to salt stress: a review. J Environ Biol 32:667-685

Yao X, Horie T, Xue S, Leung H-Y, Katsuhara M, Brodsky DE, Wu Y, Schroeder JI (2010) Differential sodium and potassium transport selectivities of the rice OsHKT2;1 and OsHKT2;2 transporters in plant cells. Plant Physiol 152:341-355

Yeo AR, Yeo ME, Flowers SA, Flowers TJ (1990) (1990) Screening of rice (Oryza sativa L.) genotypes for physiological characters contributing to salinity resistance, and their relationship to overall performance. Theor Appl Genet 79:377-384

Zhang HX, Blumwald E (2001) Transgenic salt-tolerant tomato plants accumulate salt in foliage but not in fruit. Nature 19:765-768

Zhang JL, Flowers TJ, Wang SM (2010) Mechanisms of sodium uptake by roots of higher plants. Plant Soil 326:45-60

Zhao J, Barkla BJ, Marshall J, Pittman JK, Hirschi KD (2008) The Arabidopsis cax3 mutants display altered salt tolerance, $\mathrm{pH}$ sensitivity and reduced plasma membrane $\mathrm{H}^{+}$ATPase activity. Planta 227:659-669

Zhao X, Wang YJ, Wang YL, Wang XL, Zhang X (2011) Extracellular $\mathrm{Ca}^{2+}$ alleviates $\mathrm{NaCl}$-induced stomatal opening through a pathway involving $\mathrm{H}_{2} \mathrm{O}_{2}$-blocked $\mathrm{Na}^{+}$influx in Vicia guard cells. J Plant Physiol 168:903-910

Zhu JK, Liu J, Xiong L (1998) Genetic analysis of salt tolerance in Arabidopsis: evidence for a critical role of potassium nutrition. Plant Cell 10:1181-1191 